ISSN : 2580-3220, E-ISSN : 2580-4588

J. Mandiri., Vol. 2, No. 1, Juni 2018 (201 - 225)

C2018 Lembaga Kajian Demokrasi

dan Pemberdayaan Masyarakat (LKD-PM)

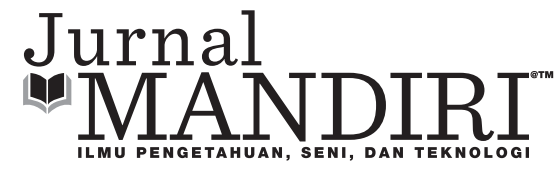

\title{
PENGARUH MINAT MEMBACA DAN PENGUASAAN KOSAKATA TERHADAP KETERAMPILAN BERPIDATO SURVEY PADA SISWA MAN DI JAKARTA
}

\author{
Zaky Mubarok \\ Fakultas Sastra, Universitas Pamulang \\ katumbiri.zaky@gmail.com
}

\begin{abstract}
Abstrak
Tujuan Penelitian Adalah 1) Pengaruh minat membaca dan penguasaan kosakata secara bersamasama terhadap keterampilan berpidato, 2) pengaruh minat membaca terhadap keterampilan berpidato, 2) pengaruh penguasaan kosakata terhadap keterampilan berpidato. Metode penlitian yang digunakan adalah survey. Populasi terjangkau adalah siswa kelas XII MAN 6 Jakarta kampus B di Jakarta Timur yang berjumlah 61 Siswa. Penlitia ini hingga penyusunan laporan dilaksanakan empat bulan. Hasil penelitian memperoleh kesimpulan, 1) Terdapat pengaruh yang signifikan minat membaca dan penguasaan kosakata secara bersama-sama terhadap keterampilan berpidato siswa MAN 6 Jakarta Timur. Hal ini dibuktikan dengan perolehan Nilai $F_{0}=F_{0}=37,514$ dan Sig. $=0,000<0,5$. Secara bersama-sama variabel minat membaca dan penguasaan kosakata memberikan kontribusi sebersar $56,4 \%$ terhadap varibel keterampilan berpidato. 2)Terdapat pengaruh yang signifikan minat membaca terhadap keterampilan berpidato siswa MAN 6 Jakarta Timur. Hal ini dibuktikan dengan perolehan nilai thitung $=2,808$ dan Sig. $=0,007<0,05$. Variabel minat membaca memberikan kontribusi sebesar 16,41\% dalam meningkatkan keterampilan berpidato. 3) Terdapat pengaruh yang signifikan penguasaan kosakata terhadap keterampilan berpidato siswa MAN 6 Jakarta. Hal ini dibuktikan dengan perolehan nilai $t_{\text {hitung }}=5,555$ dan Sig. $=0,000<0,05$. Variabel penguasaan kosakata memberikan kontribusi sebesar 39,97\% dalam peningkatan keterampilan berpidato.
\end{abstract}

Kata Kunci: Minat Membaca, Penguasaan Kosakata, dan Keterampilan Berpidato

\section{PENDAHULUAN}

\section{Latar Belakang}

Berbicara merupakan suatu keterampilan berbahasa yang terus berkembang pada setiap manusia. Keterampilan berbicara sudah tentu harus didukung oleh perbendahaaran kosakata pada penggunanya. Semakin banyak kosakata yang dimiliki dan dikuasai, semakin besar kemungkinan kemampuan dan keterampilan berbicara menjadi berkembang dan menjadi baik.
Berbicara, dalam kehidupan sehari-hari menempati posisi utama dalam berkomunikasi, baik untuk interaksi sederhana, menyampaikan pendapat, gagasan, atau pun perasaan. Berbicara, dalam lingkup berbahasa masuk dalam wilayah ragam bahasa lisan. Karenanya ia akan berbeda dengan ragam bahasa tulis. Sugono (2009:17) menyatakan bahwa ragam bahasa lisan mencakup aspek lafal, tata babaha (bentuk kata dan susunan kalimat), dan kosakata. Lafal 
merupakan aspek pembeda ragam bahasa lisan dengan ragam bahasa tulis, sedangkan ejaan merupakan aspek daya pembeda ragam bahasa tulis dengan ragam bahasa lisan. Dengan begitu, penguasaan kosakata dalam berpidato tidak hanya pada wilayah seberapa banyak kosakata yang dipahami, tetapi juga kemampuan melafalkan bentuk bunyinya. Hal ini dikuatkan oleh pendapat Bloomfield (1995), tulisan bukanlah bahasa, melainkan suatu cara untuk merekam bahasa dengan tanda-tanda yang dapat dilihat. Dengan dengan demikian, terlihatlah betapa pentingnya berbahasa lisan (berbicara-berpidato) dalam berkomunikasi sehari-hari.

Dalam praktiknya, ternyata berbicara kadang-kadang diperlukan dan bisa digunakan untukkomunikasi yanglebih formal, terstruktur, berdaya jangkau luas untuk menyampaikan gagasan dan perasaan yang lebih kompleks yakni dengan berbicara di depan orang banyak atau lebih sering disebut berpidato. Berbicara di hadapan orang banyak (public speaking) berpidato- merupakan keterampilan berbicara untuk memberi atau menanankan pengetahuan, memberikan tanggapan, menerangkan atau menjelaskan suatu proses tertentu dengan sadar tujuan penyampainya (Tarigan, 2013:30).

Di sekolah, para siswa kerap kesulitan berpidato bukan karena tidak ada ada kesempatan untuk berpidato. Tetapi di duga karena rendahnya penguasaan kosakata yang terangkai dalam bentuk kalimat dengan struktur yang baik. Rendahnya penguasaan kosakata akibat dari rendahnya pengetahuan dan kurangnya informasi pada diri mereka. Sehingga diduga, rendahnya keterampilan berpidato siswa akibat dari rendahnya pengetahuan dan penguasaan kosakata karena kurang membaca.

Membaca, seperti diketahui banyak orang, adalah kegiatan untuk mendapatkan informasi atau pesan yang ingin disampaikan oleh penulisnya. Kegiatan membaca dengan sendirinya akan menambah kosakata, pengertian-pengertian, dan pemahaman pengguna- an kata dalam struktur kalimat yang baik dan benar. Membaca akan memberikan pengetahuan kepada pembaca dan sekaligus menambah perbendaharaan kosakata. Dengan bertambahnya kosakata seseorang tentu saja ia tidak akan kesulitan dalam mengukapkan pikirannya. Tarigan (1993: 2), mengatakan bahwa kualitas keterampilan berbahasa seseorang jelas bergantung pada kuantitas dan kualitas kosakata yang dimilikinya.

Berpidato adalah keterampilan berbicara yang tidak hanya bergantung pada bakat dan talenta saja. Melainkan keterampilan yang bisa dilatih secara rutin dan terstruktur. Namun, di luar dari pelatihan yang rutin dan teratur, ada beberapa faktor yang juga bisa menambah dan diduga mempengaruhi ketarampilan berpidato, yakni, penguasaan kosakata dan minat membaca.

Minat membaca yang tinggi akan dengan sendirinya mendorong setiap orang untuk membaca. Semakin banyak membaca, dimungkinkan akan semakin banyak kosakata yang dimiliki. Semakin banyak kosakata yang dimiliki, akan berpengaruh terhadap keterampilan berbicara dan berpidato.

Mengacu pada perkiraan-perkiraan di atas, peneliti tertarik untuk melakukan penelitian guna menguji ada atau tidaknya hubungan yang signifikan antara minat membaca dan penguasaan kosakata dengan keterampilan berpidato. Untuk itu penelitian ini bertolak dari anggapan pertama, bahwa terdapat hubungan yang erat antara minat membaca dengan keterampilan berpidato, kedua, terdapat hubungan yang juga erat antara penguasaan kosakata dengan keterampilan berpidato, sehingga antara minat membaca, penguasaan kosakata dan keterampilan berpidato saling berhubungan.

\section{Pembatasan Masalah}

Berhubung banyaknya masalah yang timbul, maka penelitian ini perlu dibatasi. Hal ini dimaksudkan agar lebih tajam dan mendalam. Adapun masalah dalam penelitian ini dibatasi 
hanya mengenai pengaruh minat membaca dan penguasan kosakata terhadap keterampilan berpidato.

\section{Rumusan Masalah}

Untuk mempermudah proses penelitian, maka peneliti merumuskan penelitian ini dalam bentuk pertanyaan sebagai berikut,

1. Apakah terdapat pengaruh minat membaca dan penguasaan kosakata secara bersamasama terhadap keterampilan berpidato siswa MAN di Jakarta?

2. Apakah terdapat pengaruh minat membaca terhadap keterampilan berpidato siswa MAN di Jakarta?

3. Apakah terdapat pengaruh penguasaan kosakata terhadap keterampilan berpidato siswa MAN di Jakarta?

\section{Tujuan Penelitian}

Berdasarkan rumusan di atas, tujuan penelitian ini adalah untuk mengetahui dan mendeskripsikan,

1. Pengaruh minat membaca dan penguasaan kosakata secara bersama-sama terhadap keterampilan berpidato siswa MAN di Jakarta.

2. Pengaruh minat membaca terhadap keterampilan berpidato siswa MAN di Jakarta.

3. Pengaruh penguasaan kosakata terhadap keterampilan berpidato siswa MAN di Jakarta.

\section{Landasan Teori}

\section{Keterampilan Berpidato}

a. Pengertian berpidato

Para pakar komunikasi berpendapat bahwa hakikat berpidato adalah proses mengkomunikasikan ide, pikiran, pesan dan perasaan seseorang di hadapan orang banyak (massa). Efektifitas berpidato banyak ditentukan oleh gaya, seni, penampilan, serta keterampilan atau kemahiran dari orang yang melakukan berpidato tersebut. Dengan berpidato, maka orang yang mendengar dapat terpengaruh oleh "apa-apa" - massageyang disampaikan.

Banyak definisi yang dikemukakan oleh para ahli, misalnya dikemukakan oleh Rahmat (2002:4) bahwa berpidato adalah "seni untuk mempengaruhi orang-orang melaluii bahasa lisan (oral)". Pendapat lain dikemukaka oleh Faridh (2004:7) bahwa "berpidato adalah seni untuk menyampaikan pesan yang dilakukan secara sadar ditujukan kepada orang banyak". Pengertian yang hampir sama dengan kedua pendapat di atas disampaikan oleh Sanusi (2001:6) bahwa berpidato adalah "seni berkomunikasi untuk menyampaikan pesan dengan tujuan mempengaruhi orang banyak (massa)".

Berdasarkan beberapa pendapat di atas dapat disimpulkan bahwa berpidato adalah seni berkomunikasi untuk menyampaikan pesan dengan sadar yang ditujukan kepada orang banyak (massa) sehingga mereka terpengaruh oleh pesan yang disampaikan.

b. Jenis-jenis Pidato

Ada atau tidak adanya persiapan, sesuai dengan cara yang dilakukan, dan waktu persiapan, Rahmat (2002:17) membedakan empat macam pidato, yaitu, 1) Impromtu, 2) Manuskrip, 3) Memoriter, dan, 4) Ekstempore.

Berpidato dengan baik dan benar adalah cara berpidato yang memperlihatkan kaidah-kaidah retorika. Menurut Sanusi (2001:4-5) yang dimaksud dengan kaidah retotika yang benar adalah tahapan-tahapan yang harus diperlihatkan ketika seseorang akan sedang, dan mengakhiri pidatonya. Hal-hal penting yang harus diperlihatkan dengan sungguh-sungguh. 


\section{Minat Membaca}

a. Hakikat Minat

Berbgai pengertian minat oleh para ahli dikemukakan dengan penekanan dan pendekatan yang berbeda-beda. Minat salah satu aspek-aspek psikologi selalu berhubungan dengan aspek psikologi yang lainnya. Erat kaitan antara minat dengan aspek psikologi menjadikan banyak pengertian minat yang dikaitkan dengan aspek psikologi yang lainnya seperti, sikap, perasaan, perhatian, motivasi dan kepribadian.

Minat dikaitkan dengan pengertian sikap, baik sikap maupun minat kedua-duanya berhubungan dengan kegiatan memilih, melibatkan perasaan pribadi, yang membedakan keduanya adalah obyeknya. Obyek untuk sikap berupa intuisi sosial dan kelompok, sedangkan obyek minat berupa kegiatan. Dalam hal ini pengertian minat menggambarkan adanya kemauan, dorongan yang timbul dari dalam individu untuk memilih obyek yang berupa kegiatan termasuk di dalamnya tugas dan pekerjaan.

Minat belajar yang didorong oleh miotivasi yang tinggi akan memungkinkan timbulnya hasil belajar yang baik, sebab motivasi belajar akan mendorong pemelajar untuk belajar. Paduan minat dan motivasi akan memunculkan hasil belajar yang gemilang. Dalam kaitannya dengan membaca, pemelajar yang memiliki minat membaca yang kuat dan didorong oleh kegiatan yang kuat untuk melakukannya, maka ia akan melakukannya dengan sungguhsungguh dengan mengarahkan pikiran, tenaga, dan waktu untuk itu tanpa ada suruhan paksaan atau paksaan dari orang lain dan tidak mudah mengalihkan perhatiannya pada hal lain yang datang dari luar dirinya.

Berdasarkan konsep bahwa minat merupan motif yang dipelajari yang mendorong dan mengarahkan individu untuk mencari serta aktif dalam pekerjaan tertentu, indikatorindikator minat yang dapat diambil dan dapat dilihat dengan menganalisis: (1) keinginan untuk memiliki/mengetahui sesuatu, (2) obyek-obyek atau kegiatan-kegiatan yang disenangi, (3) jenis kegiatan untuk mencapai hal yang disenangi, (4) usaha-usaha untuk merealisasikan keinginan atau rasa senang terhadap sesuatu.

Slameto (2003:180), menyatakan bahwa minat adalah satu rasa lebih suka dan rasa keterikatan pada satu hal atau aktivitas, tanpa ada yang menyuruh. Minat pada dasarnya adalah penerimaan suatu hubungan antara diri sendiri dan sesuatu dari luar diri. Semakin kuat atau dekat hubungan tersebut, semakin besar minat.

Minat adalah keinginan jiwa terhadap suatu objek dengan tujuan untuk mencapai sesuatu yang dicita-citakan. Hal ini menggambarkan bahwa seseorang tidak akan mencapai tujuan yang dicita-citakan apabila di dalam diri orang tersebut tidak terdapat minat atau keinginan jiwa untuk mencapai tujuan yang dicita-citakannya. Minat menjadi motor penggerak untuk dapat mencapai tujuan yang diinginkan. Tanpa minat, tujuan belajar tidak akan tercapai.

b. Hakikat Membaca

Harris memberikan definisi membaca adalah suatu kegiatan menafsirkan simbol-simbol cetak. Selanjutnya Tarigan (1992:22) mendefinisikan membaca merupakan suatu proses yang dilaukan dan digunakan untuk memperoleh pesan yang di- 
sampaikan oleh penulis melalui media tulis. Burkan, dkk. menekankan pengertian membaca pada perbuatan yang dilakukan dengan sabar, berdasarkan kegiatan beberapa keterampilan, yaitu, mengamati, memahami, dan memikirkan. Selain itu, Oka menyatakan bahwa membaca adalah proses pengolahan bacaan kritis, kreatif yang dilakukan dengan tujuan memperoleh pemahaman yang bersifat menyeluruh tentang bacaan itu dan penilaian terhadap keadaan, nilai, fungsi, dan dampak bacaan itu.

Dari beberapa definisi di atas, ada persamaan yang mendasar antara keterampilan bahasa yang lain dengan membaca. Membaca mendapatkan pesan yang disampaikan oleh penulis dalam satu tulisan. Dengan demikian, berdasarkan pendapat tersebut dapat disimpulkan bahwa kegiatan membaca adalah kegiatan yang dilakukan untuk menangkap pesan menyeluruh dari seorang penulis.

c. Hakikat Minat Membaca

Minat membaca merupakan salah satu faktor yang dapat mempengaruhi kemampuan membaca seseorang. Minat membaca berhubungan dengan hasrat seseorang terhadap bacaan. Minat membaca menjadi faktor yang mendorong munculnya keinginan untuk membaca. Sundarman (1977:44) menyatakan bahwa minat membaca bersifat peribadi dan merupakan produk dari kegiatan belajar. Minat membaca merupakan landasan penting dalam mencapai keberhasilan kegiatan membaca.

Kemampuan membaca tidak akan berhasil apabila tidak didukung minat membaca yang memadai. Kebiasaan membaca yang masih rendah saat ini terjadi karena kurangnya minat membaca pada pemakai bahasa. Upaya menumbuhkan tradisi membaca atau minat membaca memang menjadi pekerjaan yang tidak mudah. Kondosi ini menyebabkan tradisi membaca masyarakat menjadi belum optimal. Kenyataan ini diperkuat oleh Sugono (1995:5) yang menyatakan bahwa tradisi membaca memang belum dapat diharapkan dari masyarakat.

Rosidi (1992:37) menyatakan bahwa minat membaca yang tinggi akan mempengaruhi keterampilan berbahasa yang lain, misalnya berbicara. Minat membaca dapat ditimbulkan dan dikembangkan melaui penguasaan teknik membaca yang tepat. Teknik membaca yang tepat dapat membuat kegiatan membaca menjadi lebih efisien, efektif, serta menarik. Upaya untuk menggalakan minat membaca pada siswa sangat diperlukan. Seorang guru diharapkan dapat memancing, menanamkan, menumbuhkan dan mengembangkan minat membaca siswa. Syamsudin (1992:74) menyatakan tentang minat membaca sebagai berikut:

Sebenarnya tujuan dari pengembangan minat membaca antara lain untuk a) mendorong minat dan kegiatan membaca, b) meningkatkan layanan perpustakaan, c) menciptakan masyarakat informasi, d) memiliki pengetahuan yang terkini, e) meningkatkan kemampuan berpikir, dan f) mengisi waktu luang.

Kasim (1989:12) menyatakan tentang upaya menggalakan minat membaca siswa sebagai berikut, upaya menggalakan minat membaca dapat dilakukan melalui penyediaan buku yang menarik, menghayati selera siswa dalam membaca, menjadikan sekolah pusat pustaka, menyediakan tempat 
membaca yang memadai.

Sudarman (1997:5) mengungkapkan beberapa faktor yang mempengaruhi kemampuan membaca. Kegiatan membaca tidak hanya membutuhkan konsentrasi semata, namun membutuhkan keterampilan yang bersifat mekanis dan pemahaman. Hal ini dimaksudkan agar pembaca dapat dengan mudah memahami isi bacaan yang dibacanya. Tidak dapat dipungkiri lagi, tujuan akhir dari kegiatan membaca adalah memperoleh pemahaman terhadap bahan bacaan. Selain itu, kegiatan membaca pun harus didukung oleh perangkat mental yang memadai. Berbagai perangkat mental yang terkait dengan kegiatan membaca diantaranya adalah minat, kemauan dan konsentrasi. Perangkat mental yang diperlukan dalam kegiatan membaca terletak pada kepribadian individu pembaca. Tanpa perangkat mental tersebut, dapat dipastikan kegiatan membaca tidak akan memenuhi tujuannya.

Minat, kemauan dan konsentrasi memiliki peran penting dalam kegiatan membaca. Seorang pembaca akan mudah memahami isi bacaan apa bila didukung dengan minat terhadap bacaan yang tinggi. Kemauan yang kuat untuk membaca pun memberikan dampak yang positif bagi terbentuknya kebiasaan membaca. Begitu pula dengan konsentrasi yang dapat memperkuat pemahaman terhadap makna bacaan. Syamsudin (1980:7) menyatakan bahwa minat dan kemauan dalam membaca berhubungan dengan reaksi yang ditimbulkan terhadap obyek bacaan yang menggambarkan individu melakukan reaksi tertentu.

Semakin sering seseorang melakukan kegiatan membaca maka semakin banyak pula informasi atau pesan yang diperolehnya. Hal ini sesuai dengan pendapat Tarigan (1992:22) yang menyatakan bahwa membaca adalah suatu kegiatan yang dilakukan pembaca untuk memperoleh pesan melalui media bahasa atau kata-kata yang disampaikan oleh penulis. Oleh karena itu, untuk bisa mendapatkan informasi dan pesan yang banyak maka kebiasaan membaca menjadi aspek yang mutlak diperlukan.

Di samping kebiasaan membaca pun membutuhkan pengetahuan dan keterampilan membaca. Hal ini sesuai dengan pernyataan Barja (1976:16) yang menyatakan bahwa membaca merupakan penyerapan seperangkat keterampilan dan pengetahuan untuk memperoleh pemahaman bahasa tertulis. Hal ini berarti kegiatan membaca tidak akan optimal tanpa pendukung keterampilan dan pengetahuan yang baik. Hal ini berarti setiap pembaca dituntut untuk memiliki keterampilan dan pengetahuan yang sesuai dengan kebutuhan aktivitas pembaca.

Minat merupakan aspek psikologis yang akan mempengaruhi membaca dan belajar. Peran minat dalam membaca adalah sebagai motivating force yaitu sebagai kekuatan yang akan mendorong sesorang untuk membaca.

The Liang Gie mengemukakan arti pentingnya minat dalam kaitannya dengan studi, 1) minat melahirkan perhatian, 2) minat memudahkan terciptanya konsentrasi, 3) minat mencegah gangguan perhatian, 4) minat memperkuat melekatnya bahan pelajaran dalam ingatan, 5) minat memperkecil kebosanan studi dalam diri sendiri (The Liang Gie, 1994:24).

Farida Rahim (2005:28) menge- 
mukakan bahwa minat membaca ialah suatu perhatian yang kuat dan mendalam disertai dengan perasaan senang terhadap kegiatan membaca sehingga dapat mengarahkan seseorang untuk membaca dengan kemauanya sendiri tanpa dorongan dari luar. Minat membaca juga merupakan perasaan senang seseorang terhadap bacaan karena adanya pemikiran bahwa dengan membaca itu dapat diperoleh kemanfaatan bagi dirinya.

Dari pendapat di atas dapat ditegaskan bahwa minat membaca terkandung unsur perhatian, kemauan, dorongan dan rasa senang untuk membaca, perhatian bisa dilihat dari perhatiannya terhadap kegiatan membaca, mempunyai kemauan yang tinggi untuk membaca, dorongan dan rasa senang yang timbul dari dalam diri maupun dari pengaruh orang lain. Semuanya itu merupakan aktivitas yang dilakukan dengan penuh ketekunan dan cenderung menetap.

\section{Penguasaan Kosakata}

Penguasaan seseorang terhadap sesuatu bahasa dapat dilakukan melalui berbagai sumber, baik melalui belajar lansung atau tidak. Penguasan bahasa dapat mempengaruhi seseorang dalam berpikir tentang apa yang dipikirkan dan menyimpannya dalam pikiran dan sewaktu-waktu dapat menggunakannya. Bloom mengatakan bahwa penguasaan merupakan peningatan suatu kegiatan yang diperoleh melalui proses belajar.

Dalam pengajaran bahasa, penguasaan kosakata merupakan penentu utama keberhasilan seseorang dalam berbahasa. Makin tinggi penguasaan kosakata seseorang, makin besar kemungkinannya untuk terampil berbahasa. Nurgiyantoro mengatakan "penguasaan kosakata dapat dibedakan ke dalam penguasaan yang bersifat reseptif fan produktif, yakni kemampuan untuk memahami dan mempergunakan kosakata". (Nurgiyantoro, 2001).

Kosakata (vocabulary) adalah himpunan kata yang diketahui oleh seseorang atau merupakan bagian dari suatu bahasa tertentu. Kosakata seseorang didefinisikan sebagai himpunan semua kata-kata yang kemungkinan akan digunakan oleh orang tersebut untuk menyusun kalimat baru. Kosakata merupakan kekayaan kata seseorang secara umum yang menggambarkan intelejensia atau tingkat pendidikan seseorang.

Kosakata memegang peranan penting dalam keterampilan berbahasa, baik secara kualitas maupun kuantitas. Usaha penguasaan kosakata siswa dalam keterampilan berbahasa, maka pengajaran kosakata perlu ditingkatkan baik dengan cara peningkatan latihan secara lisan (berpidato) maupun tulisan atau dalam bentuk karangan.

Soedjito (1992) mengatakan bahwa kosakata (perbendaharaan kata) dapat diartikan sebagai berikut, 1) semua kata yang terdapat dalam satu bahasa, 2) kekayaan kata yang dimiliki seorang pembicara atau penulis, 3) kata yang dipakai dalam satu bidang ilmu pengetahuan, dan 4) daftar kata yang disusun seperti kamus disertai penjelasan secara singkat dan praktis (Soedjito, 1992:1). Pendapat serupa seperti yang dikatakan oleh Adiwimarta (1998) bahwa kosakata adalah 1) semua kata yang terdapat dalam suatu bahasa, 2) kata-kata yang dikuasai oleh seseorang atau katakata yang dipakai oleh segolongan orang dari lingkungan yang sama, 3) kata-kata yang dipakai dalam satu bidang ilmu pengetahuan, 4) dalam linguistik, seluruh, morfem yang ada dalam satu bahasa, dan 5) daftar alfabetis disertai bahasa dan 
ketergantungannya (Adiwimarta, dkk 1998).

Berdasarkan pendapat tersebut dapat disimpulkan bahwa kosakata adalah perbendaharaan kata yang dimiliki seseorang dan dapat dipergunakan dalam komunikasi lisan maupun tulisan.

Penambahan kosakata seseorang secara umum merupakan bagian penting, baik dari proses pembelajaran suatu bahasa ataupun pengembangan kemampuan seseorang dalam satu bahasa yang sudah dikuasai.

Penguasaan kosakata adalah kesanggupan dalam memahami dan menggunakan kata dengan maknanya dalam kalimat. Seseorang akan berusaha berkomunikasi dengan baik dan lancar agar yang diajak berkomunikasi memahami yang diungkapkan begitupun sebaliknya. Untuk dapat berkomunikasi dengan baik dan lancara tentunya harus memiliki perbendaharaan kata yang baik. Makin banyak perbendaharaan kata yang dikusai makin banyak ide atau gagasan yang akan disampaikan.

Perbendaharaan kata atau kosakata dapat dikuasai bila rajin membaca dan melakukan berdiskusi hal-hal yang menarik untuk didiskusikan. Melalui kegiatan tersebut, penguasaan kosakata secara kualitatif adalah penguasaan makna dasar dan makna tambahan dari sebuah kata yang ada di dalamnya.

Senada dengan Akadiah (1986), penguasaan kosakata dapat dibedakan berdasarkan dua sudut, yaitu sudut kuantitatif dan kualitatif. Penguasaan kosakata secara kuantitatif berarti cakupan kosakata yang dikuasai seorang dari sudut bahasa, sedangkan penguasaan kosakata secara kualitatif berarti pemahaman makna kosakata yang dikuasai oleh seseorang. Seperti telah diungkapkan di atas bahwa penguasaan kosakata adalah memahami makna kata. Menurut Soedjito (1992) makna kata adalah hubungan antara bentuk dan barang (hal) yang diacak. Pendapat lain diungkapkan oleh Kerraf (1991) bahwa makna kata adalah hubungan antara bentuk dengan hal atau barang yang diwakilinya. Hal yang dibahas dalam makna kata adalah makna leksikal dan gramatikal, denotasi dan konotasi, sinonim dan antonim, homonim (momofon dan homograf), polisemi, dan hiponimi.

Kosakata atau perbendaharaan kata merupakan jumlah seluruh kata dalam satu bahasa, juga kemampuan kata-kata yang diketahui dan digunakan seseorang dalam berbicara dan menulis. Kosakata dari suatu bahasa itu selalu mengalami perubahan dan perkembangan karena kehidupan yang semakin kompleks. Seseorang harus memiliki kosakata yang cukup untuk bisa memahami apa yang dibaca dan didengar, bisa berbicara dan menulis dengan kata yang tepat sehingga dipahami oleh orang lain. Secara singkat dapat dikatakan bahwa penguasaan kosakata menyangkut penguasaan bentuk kata dan makna.

Kosakata diperoleh pada pendidikan formal melalui proses pengajaran dan pembelajaran. Dengan penguasan kosakata, seseorang dapat berkomunikasi dengan orang orang lain secara lisan maupun tulisan tanpa mengalami hambatan. Penguasaan kosakata yang baik dapat memberikan kontribusi yang banyak dalam kegiatan berbahasa salah satunya berpidato atau berbicara.

Penguasaan merupakan suatu keterampilan atau kepandaian yang dimiliki seseorang. Dalam KKBI (2008) disebutkan bahwa penguasaan merupakan pemahamann dan kesanggupan untuk menggunakan suatu pengetahuan. Pengetahuan yang hendak dikuasai tentunya harus dimiliki seseorang. Demikian halnya dalam pengetahuan berbahasa sebagai sarana 
komunikasi.

Pengertian kosakata menurut Kridalaksana (1993) kosakata sama dengan leksikon. Leksikon adalah, 1) Komponen bahasa yang memuat semua informasi tentang makna dan pemakaian kata dalam bahasa. 2) Kekayaan kata yang dimiliki seorang pembicara, penulis, atau suatu bahasa, 3) Daftar kata yang disusun seperti kamus, tetapi dengan penjelasan singkat dan praktis.

Penguaasaan kosakata pada individu dimulai dari pengenalan bahasa ibu melalui proses pembudayaan alami. Dengan berkembangnya usia, kemudian kosakata diperoleh pada pendidikan formal melalui proses pengajaran dan pembelajaran. Dengan penguasaan kosakata, seseorang dapat berkomunikasi dengan orang lain secara lisan maupun tulisan tanpa mengalami hambatan. Penguasaan kosakata yang baik akan dapat memberikan kontribusi banyak dalam kegiatan berbahasa.

Selanjutnya, hasil penelitian Staehr (2008) menunjukkan bahwa penguasaan kosakata memiliki hubungan yang mantap dan signifikan dengan keempat keterampilan berbahasa yakni menyimask, membaca, dan menulis. Berkaitan dengan keterampilan menulis ekspresif Britton dalam Collins \& Parkhurst (1996:279) mengatakan bahwa penulisan ekspresif adalah satu jembatan yang sempurna untuk membuat dua kategori tentang penulisanpenulisan tanggapan dan penulisan puisi, karena model penulisan tersebut paling banyak digunakan para kalangan siswa. Di sini penulisan tanggapan diartikan penulisan ilmiah dan penulisan puisi dikategorikan penulisan karya sastra.

Buku dengan judul Pengantar Pemahaman Bahasa Manusia oleh Soenjono (2003) mengungkapkan temuan bahwa anak usia lima tahun sudah bisa menguasai nomina lebih banyak daripada verba, setelah itu adjektiva dan kata fungsi di urutan keempat. Pemahaman kosakata pada anak tergantung pada lingkungan si anak beradaptasi dan sesuai dengan tingkatan umumnya. Terhadap pemahaman kosakata bila sering diucapkan dan didengar si anak akan mudah dan cepat dipahami. Buku tersebut menambah wawasan dan dapat dipakai acuan untuk mendapatkan konsep atau teori. Pemahaman kosakata tergantung dari tingkatan umur dan anak akan cepat menguasai kosakata bila sering diucapkan dan didengar.

Motifasi Integratif dan Instrumental: Sejauh mana Relevansinya dalam Pembelajaran Bahasa oleh Willy (2000) memuat pernyataan dalam kegiatan belajar mengajar siswa di kelas akan berdampak praktis bila memaparkan konsep motivasi integratif dan instrumental yang akan membuat siswa lebih termotivasi untuk berusaha lebih besar dan lebih konsisten dalam menguasai bahasa.

Jadi pemahaman penguasaan kosakata tergantung dari tingkatan umur, anak akan cepat menguasai kosakata bila sering diucapkan dan didengar. Kosakata merupakan satuan garamatikal untuk menyampaikan maksud dan tujuan dalam menggunakan bahasa.

Berdasarkan uraian yang telah penulis ungkapkan di atas dapat disimpulkan bahwa yang dimaksud dengan penguasaan kosakata adalah kemampuan memahami dan menggunakan sejumlah kata dalam bahasanya termasuk makna yang dimiliki oleh kosakata tersebut. Makna kata itu meliputi makna denotatif, konotatif, makna leksikal, makna gramatikal, sinonim, antonim, homonim, homofon, homograf, polisemi dan hiponimi.

\section{Kerangka Berpikir}

1. Pengaruh penguasaan kosakata dan minat membaca terhadap keterampilan berpidato 
Keterampilan berpidato adalah keterampilan berbicara yang membutuhkan penguasaan kosakata yang tinggi dan minat membaca yang tinggi, oleh karena itu agar seseorang menjadi terampil berpidato memerlukan juga proses latihan yang berkala.

Seseorang yang penguasaan kosakatanya baik dan minat membacanya tinggi serta sering berlatih berpidato maka ia berpeluang besar untuk menjadi terampil dalam berpidato. Sebaliknya, seseorang yang tingkat penguasaan kosakatanya rendah dan minat membacanya rendah pula, maka akan berkaibat sukar dalam menyampaikan pikiran dan perasaannya melalui berpidato di depan orang banyak.

Berdasarkan beberapa teori di atas diketahui bahwa ada dua faktor yang dapat menentukan keterampilan berpidato, yakni, penguasaan kosakata dan minat membaca. Artinya semakin tinggi tingkat penguasaan kosakata dan minat membacanya maka akan semakin baik pula ia berpidato. Sebaliknya, seseorang yang tingkat penguasaan kosakatanya dan minat membacanya rendah, maka, ia akan lemah pula dalam berpidato.

2. Pengaruh penguasaan kosakata terhadap keterampilan berpidato

Penguasaan kosakata memainkan peran sentral dalam keterampilan berbahasa baik lisan atau tulisan yang tidak bisa disangkal oleh siapa pun. Mengetahui suatu kata berarti mengetahui kemungkinan kata lain yang akan muncul bersamaan dengan kata itu dalam bahasa tulisan maupun bahasa lisan. Mengetahui suatu kata berarti mengetahui batas-batas penggunaan kata tersebut sesuai ragam, fungsi dan situasinya. Mengetahui suatu kata mencakup pengetahuan tentang jaringan pengetahuan antara kata itu dengan kata lain dalam bahasa yang bersangkutan, mengetahui nilai makna kata, serta mengetahui makna- makna turunan dari kata tersebut.

Berdasarkan hal di atas tampaklah bahwa penguasaan kosakata menentukan keterampilan berpidato. Dengan perkataan lain penulis berasumsi bahwa penguasaan kosakata dapat mempengaruhi keterampilan berpidato. Karena itu semakin baik penguasaan kosakata, maka, semakin baik berpidato. Sebaliknya, semakin buruk penguasaan kosakata, maka, akan semakin buruk pula keterampilan berpidato.

3. Pengaruh minat membaca terhadap keterampilan berpidato

Seseorang dapat berpidato dengan baik karena memiliki pengalaman dari latihan pengetahuan luas dari membaca. Informasi-informasi yang ia dapatkan dari membaca diekspresikan dalam berpidato. Membaca sebagai model awal dapat mempengaruhi terhadap penguasaan diksi, gaya bahasa, perbendaharan kata, penambahan pengetahuan, akan menjadi modal untuk berpidato.

Siswa yang mempunyai minat membaca tinggi dalam proses pembelajaran akan memiliki kesadaran dan dorongan dari dalam dirinya sebab memiliki rasa ketertarikan tersendiri pada suatu aktifitas akan membuat dirinya mudah untuk menyerap informasi dan mudah mempunyai empati dan perhatian terhadap pelajaran. Dalam pembelajaran siswa yang memiliki minat baca tinggi cenderung lebih aktif dalam menggali informasi terhadap materi yang disampaikan oleh gurunya. Sehingga tugas-tugas yang diberikan gurunya akan dikerjakan dengan cepat dan baik.

Siswa yang memiliki minat membaca tinggi dapat dengan sendirinya menambah wawasan dan pengetahuannya melalui kegiatan membaca di mana pun ia berada. Dengan membaca, ia mendaptkan banyak informasi, menguasai gaya bahasa, dan akan dengan mudah menyampaikan pikiran, ide, gagasan dan pernyataannya melalui pidato. 
Oleh karena itu, dapat ditegaskan bahwa siswa yang memiliki minat membaca tinggi ia berpeluang menjadi terampil dalam berpidato. Sebaliknya, siswa yang minat membacanya rendah ia akan kesulitan dan kurang terampil dalam berpidato.

\section{METODOLOGI PENELITIAN}

\section{Tempat dan Waktu Penelitian}

Penelitian ini dilaksanakan di MA Negeri Jakarta. Sedangkan waktu penelitian dilaksanakan selama empat bulan.

\section{Metode Penelitian}

Metode yang digunakan dalam penelitian ini adalah deskriptif yakni prosedur pemecahan masalah yang terjadi pada saat sekarang dengan cara melukiskan fakta yang ada di lapangan (fact finding) sebagaimana adanya. Sedangkan teknik analisis yang digunakan adalah korelasional.

\section{Variabel Penelitian}

Variable yang diteliti sebanyak tiga variabel, yaitu, penguasaan kosakata $\left(\mathrm{X}_{1}\right)$ dan minat membaca $\left(\mathrm{X}_{2}\right)$ sebagai variabel bebas, dan keterampilan berpidato $(\mathrm{Y})$ sebagai variabel terikat.

Konstelasi variabel yang diteliti sebagai berikut:

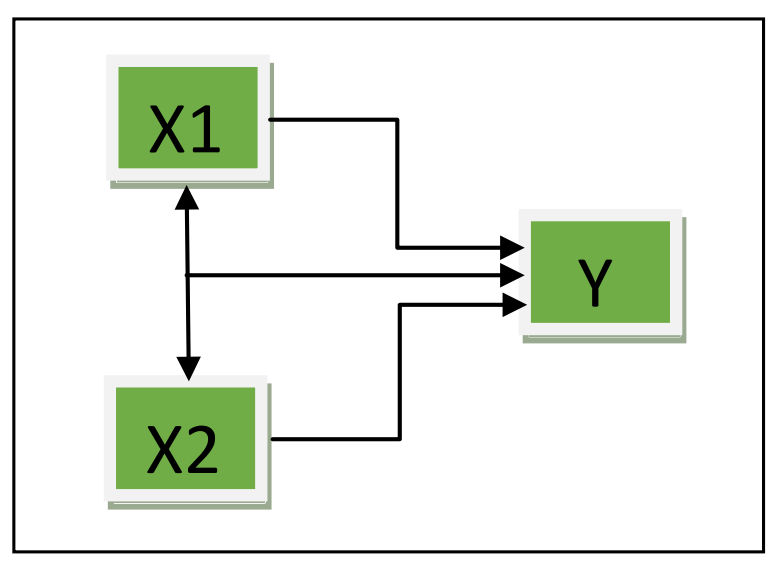

Gambar 3.1: Konstelasi Variabel

Keterangan:

$\mathrm{X}_{1}=$ Minat Membaca

$\mathrm{X}_{2}=$ Penguasaan Kosakata

$\mathrm{Y}=$ Keterampilan Berpidato

\section{Populasi dan Sampel}

1. Populasi

Adapun populasi dalam penelitian ini adalah seluruh siswa Madrasah Aliyah Negeri 6 Jakarta Timur yang berjumlah 780 siswa, adalah populasi yang tak terjangkau, sedangkan yang terjangkau adalah semua siswa kelas XII MAN 6 Jakarta.

2. Sampel

Pengambilan sampel dilakukan dengan menggunakan multi stage random sampling (pengambilan secara acak melalui beberapa tahap), berdasarkan random. Pertama, menentukan MAN 6 Jakarta sebagai tempat penelitian. Kedua, melihih siswa MAN 6 yang berada di kampus B Cibubur yang berjumlah 335. Ketiga, menetapkan siswa kelas XII sebagai kelas penelitian secara purposive sampling. Dan keempat, peneliti memutuskan mengambil $18 \%$ dari 335 siswa yakni 61 orang siswa yang akan dijadikan sampling untuk peneliatian.

\section{Teknik Pengumpulan Data}

Pengumpulan data penelitian ini dilakukan sesuai dengan jenis data penelitian yakni data primer dan data sekunder. Untuk mengumpulkan data primer dilakukan dengan metode survey dan data dikumpulkan dari siswa MAN 6 Jakarta yang menjadi subyek penelitian melalui pernyataan-pernyataan yang tertuang dalam kuisioner juga menggunakan wawancara berkaitan dengan topik-topik penelitian ini.

Kuisioner dalam penelitian ini didesain secara sederhana dan menarik sehingga memudahkan subyek penelitian memberikan jawaban secara obyektif yang dianalisis menggunakan skala Likert. Pernyataan-pernyataan dalam angket penelitian ini diberi skor (1) untuk jawaban yang sangat tidak setuju, skor (2) untuk jawaban tidak setuju, skor (3) untuk jawaban netral, skor (4) untuk jawaban setuju, dan skor (5) untuk jawaban sangat setuju. 


\section{Instrumen Penelitian}

\section{Instrumen penelitian untuk variabel bebas}

1. Minat Membaca

a. Definisi Konseptual

Minat membaca adalah sesuatu yang dapat membangkitkan atau mendorong seseorang untuk menjadi rajin membaca dan selalu berusaha untuk mengetahui seseuatu yang ada di setiap bahan bacaan yang dia temukan.

b. Definisi Operasional

Minat membaca adalah skor yang diperoleh dari siswa setelah menjawab angket yang diberikan kepada siswa yang menjadi responden penelitian.

c. Kisi-Kisi Instrumen

Tabel 3.2: Kisi-kisi Intrimen Minat Baca Siswa

\begin{tabular}{|l|l|c|c|c|}
\hline Variable & \multicolumn{1}{|c|}{ Indikator } & Jml & Positif & Negatif \\
\hline $\begin{array}{l}\text { Minat } \\
\text { Baca } \\
\text { Siswa }\end{array}$ & $\begin{array}{l}\text { Rasa Ingin tahu } \\
\text { siswa terhadap } \\
\text { sebuah } \\
\text { informasi }\end{array}$ & 7 & $1,3,12,21,29,31$ & 4 \\
\hline $\begin{array}{l}\text { Keinginan } \\
\text { siswa dalam } \\
\text { mempelajari } \\
\text { ilmu } \\
\text { pengetahuan }\end{array}$ & 8 & $2,5,6,14,22,23$ & 7,32 \\
\hline $\begin{array}{l}\text { Keaktifan } \\
\text { siswa dalam } \\
\text { mengunjungi } \\
\text { perpustakaan } \\
\text { sekolah }\end{array}$ & 7 & $\begin{array}{l}10,17,27,24, \\
25,26\end{array}$ & 13,35 \\
\hline $\begin{array}{l}\text { Memiliki } \\
\text { wawasan yang } \\
\text { luas }\end{array}$ & 6 & $8,11,18,27,28$ & 20 \\
\hline $\begin{array}{l}\text { Kegiatan } \\
\text { siswa dalam } \\
\text { membaca } \\
\text { buku-buku }\end{array}$ & 7 & $9,15,16,19,30$ & 33,34 \\
\hline
\end{tabular}

\section{Penguasaan Kosakata}

a. Defini Konseptual

Kemampuan penguasaan kosakata merupakan kemampuan gramatikal siswa untuk menyampaikan maksud dan tujuan dalam menggunakan bahasa.

b. Definisi Operasional

Keampuan penguasaan kosakata merupakan skor atau nilai yang diperoleh dari siswa setelah menjawab soal yang diberikan kepada siswa yang menjadi responden penelitian.

c. Kisi-Kisi Instrumen

Tabel 3.3: Kisi-kisi Instrumen Penguasaan

Kosakata

\begin{tabular}{|c|l|l|c|} 
No & $\begin{array}{c}\text { Komponen Penguasaan } \\
\text { Kosakata }\end{array}$ & \multicolumn{1}{|c|}{ Nomor Soal } & Total \\
\hline 1 & Bentuk kata & $1,4,6,21,22$ & 5 \\
\hline 2 & Denotatif, Konotatif & $2,3,5$ & 3 \\
\hline 3 & Sinonim & $8,10,12,19$ & 4 \\
\hline 4 & Antonim & $7,13,16$ & 3 \\
\hline 5 & Makna ata & $14,17,26$ & 3 \\
\hline 6 & Idiomatik & $18,24,25$ & 3 \\
\hline 7 & Kata yang tepat & $15,27,23$ & 3 \\
\hline 8 & Homonimi, homograf & $9,11,28$ & 3 \\
\hline 9 & Kata penanda jamak & $20,29,30$ & 3 \\
\hline & \multicolumn{2}{|c}{ Total } & 30 \\
\hline
\end{tabular}

3. Keterampilan Berpidato

a. Definisi Konseptual

Keterampilan berpidato adalah kemampuan siswa dalam seni berkomunikasi yang sadar tujuan untuk menyampaikan pesan-pesan kepada orang banyak (massa) sehingga mereka terpengaruh atas pesan-pesan tersebut.

b. Definisi Operasional

Keterampilan berpidato merupakan skor atau nilai yang diperoleh dari siswa setelah praktek berpidato bagi siswa yang menjadi responden penelitian.

c. Kisi-Kisi Instrumen

Tabel 3.4: Kisi-kisi Instrumen Keterampilan

Berpidato

\begin{tabular}{|c|l|r|r|} 
No. & \multicolumn{1}{|c|}{ Indikator } & Bobot & $\begin{array}{c}\text { Keterangan } \\
\text { Skor }\end{array}$ \\
\hline 1 & vokal & $5-10$ & \\
\hline 2 & Tema & $5-10$ & \\
\hline 3 & Penguasaan Materi & $10-20$ & \\
\hline 4 & Komunikasi & $10-20$ & \\
\hline 5 & Gaya Bahasa & $10-20$ & \\
\hline 6 & Penampilan & $5-10$ & \\
\hline 7 & Ekspresi & $5-10$ & \\
\hline & Jumlah & $50-100$ & \\
\hline
\end{tabular}




\section{Teknik Analisis Data}

\section{Statistik Deskriptif}

Dalam statistik deskriptif akan dilakukan teknik penyajian data dalam bentuk tabel distribusi frekwensi, grafik/diagram batang untuk masing-masing variabel. Selain itu juga masing-masing variabel akan diolah dan dianalisis ukuran pemutusan dan letak seperti, mean, modus, dan median serta ukuran simpangan seperti jangkauan, variasi, simpangan baku, kemencengan dan kuortis.

Adapun langkah-langkah pembuatan label distribusi frekwensi dan penyajian grafik poligon serta historis dilakukan dengan langkah-langkah sebagai berikut:

a. Menentukan rentang (R), yaitu data terbesar dikurangi data terkecil.

b. Menentukan banyak kelas (K) dengan aturan Sturges, yaitu $K=1+3,3 \log n, n$ = banyaknya data

c. Menentukan panjang kelas interval (P) yaitu, $P=\underline{\text { Rentang }}$ Banyaknya Kelas

d. Menentukan ujung bawah interval kelas pertama, yaitu

e. Membuat tabel distribusi frekwensi secara lengkap, dengan jelas jalan menentukan ujung bawah (UB) dan ujung atas (UA) setiap interval kelas mengitung banyaknya (frekwensi) data untuk masing-masing kelas interval.

f. Menggambar grafik histigram, dengan terlebih dahulu menentukan tepi bawah (TB) dan tepi atas (TB) untuk masing-masing kelas interval, yaitu, $\mathrm{TB}=\mathrm{TB}-1 / 2$ satuan data, dan $\mathrm{TA}=$ $\mathrm{TA}-\mathrm{UA}+1 / 2$ satuan data.

g. Menentukan grafik poligon frekwensi, dengan terlebih dahulu menentukan nilai tengah $\left(\mathrm{Y}_{1}\right)$ masing-masing kelas interval, yaitu $\mathrm{Y}_{1}=1 / 2(\mathrm{UA}-\mathrm{AB})$.

Sedangkan ukuran pusat dan simpangan diantaranya dapat ditentukan rumus-rumus berikut: a. Menentukan mean/rata-rata (Y) dengan rumus:

$$
\mathrm{Y}=\frac{\sum y_{i . f i}}{n}
$$

b. Menentukan Modus (Mo), dengan rumus:

$$
\begin{aligned}
\mathrm{M}_{\mathrm{o}}= & \mathrm{b}+\mathrm{p}\left(\frac{\mathrm{b}_{1}}{\mathrm{~b}_{1}+\mathrm{b}_{2}}\right) \text { Di mana: } \\
\mathrm{Mo}= & \text { Modus } \\
\mathrm{b}= & \text { batas bawah kelas modus, ialah kelas } \\
& \text { interval dengan kelas terbanyak } \\
\mathrm{p}= & \text { panjang kelas } \\
\mathrm{b}_{1}= & \text { Frekwensi kelas modus dikurangi } \\
& \text { frekwensi kelas interval terdekat } \\
& \text { sebelumnya } \\
\mathrm{b}_{2}= & \text { Frekwensi kelas modus dikurangi } \\
& \text { frekwensi kelas interval terdekat } \\
& \text { sesudahnya }
\end{aligned}
$$

c. Menentukan Median (Me), dengan rumus:

$$
\begin{aligned}
\mathrm{M}_{\mathrm{e}}= & \mathrm{b}+\mathrm{p}\left(\frac{\frac{1}{2} n-F}{f}\right) \\
\mathrm{M}_{\mathrm{e}}= & \text { median } \\
\mathrm{n}= & \text { banyak data/ jumlah seluruh } \\
& \text { frekwensi } \\
\mathrm{F}= & \text { Jumlah semua kelas Frekwensi } \\
& \text { sebelum kelas median } \\
\mathrm{f}= & \text { Frekwensi kelas median } \\
\mathrm{b}= & \text { batas bawah kelas media } \\
\mathrm{p}= & \text { panjang kelas median }
\end{aligned}
$$

d. Variasi (SD) dan Simpangan Baku, dengan rumus:

$$
\mathrm{SD}=\sum_{\mathrm{i}=1}^{\mathrm{k}} \frac{\mathrm{Yi}^{2} \cdot \mathrm{fi}}{\mathrm{n}}-\left(\sum \frac{\mathrm{Yi} \cdot \mathrm{fi}}{\mathrm{n}}\right)^{2} \cdots
$$

Untuk mempersingkat waktu, sekaligus pemanfaatan teknologi, maka perhitungan statistik deskriptif dalam penelitian ini akan diselesaikan dengan menggunakan program komputer SPSS 20.0

2. Uji persyaratan analisis data

\section{a. Uji Normalitas}

Uji normalitas bertujuan untuk mengetahui apakah data hasil 
pengumpulan berdistribusi normal atau baik. Hal ini akan berpengaruh pada proses lanjutan analisis statistik, jika data berdistribusi dengan normal, maka analisis dilanjutkan menggunakan statistik pametrik, sedangkan jika data tidak berdistribusi dengan normal, maka analisis dilanjutkan menggunakan statistik non parametrik. Uji normalitas dalam penelitian menggunakan analisis Kolmogorov Smirnov dalam program SPSS 20.0 ditunjukan oleh tabel Test of Normality pada kolom Sig untuk pengujian teknik Kolmogorov Smirnov. Kriteria kenormalannya adalah jika Sig KS > 0,05 maka data tersebut dikatakan berdistribusi dengan normal.

b. Uji Linearitas

Pengujian kiniearitas garis regresi dalam penelitian ini digunakan uji F. Rumusnya adalah sebagai berikut (Sudjana, 1996:327):

$$
\mathrm{F}=\frac{\mathrm{S}_{\mathrm{TC}}^{2}}{\mathrm{~S}_{\mathrm{E}}^{2}}=\frac{\frac{\mathrm{JK}(\mathrm{TC})}{\mathrm{k}-2}}{\frac{\mathrm{JK}(\mathrm{E})}{\mathrm{n}-\mathrm{k}}}
$$

Dalam prakteknya, akan digunakan bantuan SPSS 20.0 untuk menghitung uji linearitas, yaitu dengan melihat besarnya nilai koefisien Sig pada Deviation from Linearity.

Kriteria pengujian linearitas sebagai berikut,

- $\quad$ Jika Sig > 0,05 maka garis regresi tersebut linear, dan

- Jika Sig < 0.05 maka garis regresi tersebut tidak linear.

\section{Uji Hipotesis Penelitian}

Setelah keseluruhan uji persyaratan data dipenuhi dan diketahui data layak untuk diolah lebih lanjut, maka langkah berikutnya adalah menguji masing-masing hipotesis yang telah diajukan. Pengujian hipotesis menggunakan teknik korelasi partial dan korelasi ganda, serta regresi linier sederhana dan regresi linier ganda.

Dalam prakteknya, untuk penghitungan dan pengujian korelasi dan regresi baik partial maupun ganda akan digunakan program komputer SPSS 20.0. Ada pun kriterianya sebagai berikut:

a. Analisis Korelasi

1) Perhitungan dan pengujian signifikansi koefisien korelasi partial

Hasil penghitungan koefisien korelasi partial bisa dilihat dari output program SPSS melalui analisis korelasi yakni pada tabel Correlation. Signifikansi dari koefisien korelasi tersebut dinyatakan oleh keterangan yang ada di bawah tabel tersebut, yaitu:

- Untuk tanda ** (dua bintang) maka koefisien korelasi tersebut signifikan pada taraf $1 \%$.

- Untuk tanda * (satu bintang) maka koefisien tersebut signifikan pada taraf nyata 5\% berarti tidak signifikan pada taraf nyata $1 \%$.

- Untuk yang tidak ada tanda bintangnya maka koefisien korelasi tersebut tidak signifikan.

2) Perhitungan dan pengujian signifikansi koefisien korelasi ganda Hasil perhitungan koefisien korelasi ganda bisa dilihat dari output program SPSS melalui analisis regresi yakni pada tabel Model Sumerry ${ }^{b}$. Signifikansi dari koefisien korelasi tersebut diuji secara manual atau dengan bantuan komputer melalui program microsoft Exel. Adapun rumus pengujian adalah: 


$$
F=\frac{\frac{R^{2}}{k}}{\frac{1-R^{2}}{n-k-1}}
$$

di mana

$\mathrm{R}=$ Ry.12 yaitu koefisien korelasi ganda

$\mathrm{n}$ = banyaknya anggota sample

$\mathrm{k}$ = banyaknya variable bebas

b. Analisis Regresi

1) Perhitungan persamaan garis regresi

Hasil perhitungan garis regresi bila dilihat dari output program SPSS melalui regresi yakni pada tabel Coefficients ${ }^{a}$. Koefisienkoefisien persamaan garis regresi ditunjukan oleh bilangan-bilangan yang ada pada kolom B untuk Unstandarized Coefficient.

Tabel 3.5: Tabel Koefissien

Coefficients $^{a}$

\begin{tabular}{|c|l|c|c|c|c|c|}
\hline \multirow{2}{*}{ Model } & \multicolumn{2}{|c|}{$\begin{array}{c}\text { Unstandardized } \\
\text { Coefficients }\end{array}$} & $\begin{array}{c}\text { Standardized } \\
\text { Coefficients }\end{array}$ & \multirow{2}{*}{ t } & \multirow{2}{*}{ Sig. } \\
\cline { 2 - 6 } & B & $\begin{array}{c}\text { Std. } \\
\text { Error }\end{array}$ & Beta & & \\
\hline \multirow{2}{*}{1} & (Constant) & $\mathrm{A}_{0}$ & & & & \\
\cline { 2 - 6 } & $\mathrm{a}_{1}$ & & & $\mathrm{t}_{1}$ & \\
\hline $\mathrm{X}_{1}$ & $\mathrm{a}_{2}$ & & & $\mathrm{t}_{2}$ & \\
\hline
\end{tabular}

Dari tabel di atas maka persamaan regresinya adalah $\mathrm{Y}=\mathrm{a}_{0}+\mathrm{a}_{1} \mathrm{X}_{1}+\mathrm{a}_{1} \mathrm{X}_{2}$

2) Pengujian signifikansi regresi

a. Untuk regresi Partial

Untuk pengujian signifikansi regresi partial dilakukan dengan memperhatikan nilai pada kolom $\boldsymbol{t}$ atau kolom Sig. pada tabel Coefficients. Untuk regresi partial pengaruh $\mathrm{X}_{1}$ terhadap $\mathrm{Y}$ digunakan barit $\boldsymbol{t}$ dan Sig pada variable $\mathrm{X}_{1}$, sedangkan untuk regresi partial pengaruh $\mathrm{X}_{2}$ terhadap $\mathrm{Y}$ digunakan baris nilai $\boldsymbol{t}$ dan $\boldsymbol{S i g}$ pada variabel $\mathrm{X}_{2}$.

- Jika digunakan kolom Sig, maka kriteria signifikansinya adalah: "Jika Sig $<0,05$ maka regresi tersebut signifikan".

- Jika digunakan kolom $\boldsymbol{t}$, maka kriteria pengujian signifikansinya adalah: "Jika $\mathrm{t}_{\text {hitung }}>\mathrm{t}_{\text {tabel }}$ maka regeresi tersebut signifikan".

- $\mathrm{t}_{\text {tabel }}$ dipilih dengan ketentuan pengujian statistik pada distribusi $\boldsymbol{t}$, yaitu nyata $\alpha$ dan $\mathrm{dk}=\mathrm{n}-2$, dimana $n$ adalah banyaknya anggota sample.

b) Untuk regresi Ganda

Hasil pengujian signifikansi regresi ganda bisa dilihat dari output program SPSS melalui analisis regresi yakni pada tabel

ANOVA $^{b}$ kolom F atau Sig.

Tabel 3.6: tabel ANOVA

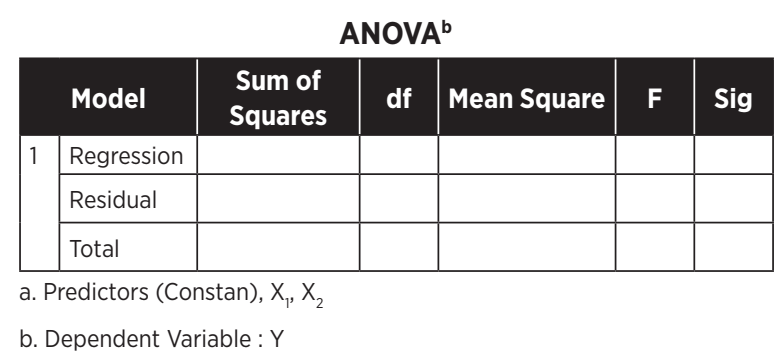

Kriteria signifikansinya adalah:

- Jika digunakan kolom Sig, maka kriteria signifikansinya adalah, "Jika Sig $<0,05$ maka garis regresi tersebut signifikan".

- Jika digunakan kolom F, maka kriteria signi- 
fikansinya adalah, "Jika $\mathrm{F}_{\text {hitung }}>\mathrm{F}_{\text {tabel }}$ maka garis regresi tersebut signifikan".

- $\mathrm{F}_{\text {tabel }}$ dipilih sesuai dengan ketentuan pengujian statistik pada distribusi F, yaitu pada taraf nya a derajat ( $\mathrm{dk}$ ) pembling $=\mathrm{k}$ dan derajat (dk) penyebut $=\mathrm{n}-\mathrm{k}-1$, dimana $\mathrm{n}$ adalah banyaknya anggota sampel dan $\mathrm{k}$ adalah banyaknya variabel bebas.

\section{Hipotesis Statistik}

Terdapat tiga hipotesi penelitian yang akan diuji dalam penelitian ini. Secara statistik ketiga hipotesis penelitian tersebut dapat dirumuskan sebagai berikut:

1. $\mathrm{H}_{0}=\beta_{\mathrm{y} 1}=\beta_{\mathrm{y} 2}=0$

$\mathrm{H}_{1}=\beta_{\mathrm{y} 1} \neq 0$ atau $\beta_{\mathrm{y} 2} \neq 0$

Artinya,

$\mathrm{H}_{0}=$ tidak terdapat pengaruh yang signifikan minat membaca dan penguasaan kosakata secara bersama-sama terhadap keterampilan berpidato siswa.

$\mathrm{H}_{1}=$ terdapat pengaruh yang signifikan minat membaca dan penguasaan kosakata secara bersama-sama terhadap keterampilan berpidato siswa.

2. $\mathrm{H}_{0}: \mathrm{B}_{\mathrm{y} 1}$

$\mathrm{H}_{1}: \beta_{\mathrm{y} 1} \neq 0$

Artinya,

$\mathrm{H}_{0}=$ tidak terdapat pengaruh yang signifikan minat membaca terhadap keterampilan berpidato siswa

$\mathrm{H}_{1}=$ terdapat pengaruh yang signifikan minat membaca terhadap keterampilan berpidato siswa.

3. $\mathrm{H}_{0}: \mathrm{B}_{\mathrm{y} 2}$

$\mathrm{H}_{1}: \mathrm{B}_{\mathrm{y} 2} \neq 0$

Artinya,

$\mathrm{H}_{0}=$ tidak terdapat pengaruh yang signi- fikan penguasaan kosakata terhadap keterampilan berpidato siswa.

$\mathrm{H}_{1}=$ terdapat pengaruh yang signifikan penguasaan kosakata terdapat keterampilan berpidato siswa.

\section{HASIL PENELITIAN DAN PEMBAHASAN}

Pada bagian ini peneliti akan menyajikan data penelitian untuk variable keterampilan berpidato $(\mathrm{Y})$, minat membaca $\left(\mathrm{X}_{1}\right)$, dan penguasaan kosakata $\left(\mathrm{X}_{2}\right)$.

\section{Deskripsi Data}

1. Data Keterampilan Berpidato $(\mathrm{Y})$

Data keterampilan berpidato diperoleh dari nilai tes siswa yang menjadi sample penelitian sebanyak 61 siswa. Nilai yang diperoleh adalah terendah 56 , tertinggi 85 , rata-rata sebesar 73,86 , median sebesar 78 , modus sebesar 78, dan simpangan baku sebesar 7,643.

Tabel 4.1 Deskripsi Data Penelitian Keterampilan Berpidato

Statistics

\begin{tabular}{|l|l|r|}
\hline \multirow{2}{*}{$N$} & Valid & 61 \\
\cline { 2 - 3 } & Missing & 0 \\
\hline \multirow{4}{*}{} & Mean & 73,8689 \\
\cline { 2 - 3 } & Median & 78,0000 \\
\cline { 2 - 3 } & Mode & 78,00 \\
\cline { 2 - 3 } & Std. Deviation & 7,64303 \\
\cline { 2 - 3 } & Minimum & 56,00 \\
\cline { 2 - 3 } & Maximum & 85,00 \\
\hline
\end{tabular}

Bila dilihat dari hasil perhitungan di atas, maka bisa dikatakan bahwa keterampilan berpidato siswa MAN 6 Jakarta kampus B tergolong cukup. Hal ini diindikasikan dengan perolehan nilai rata-rata 73,86 .

Untuk memperjelas data di atas, digambarkan dalam histogram sebagai berikut: 
Gambar 4.1 : Histogram Poligon Variable Keterampilan Berpidato

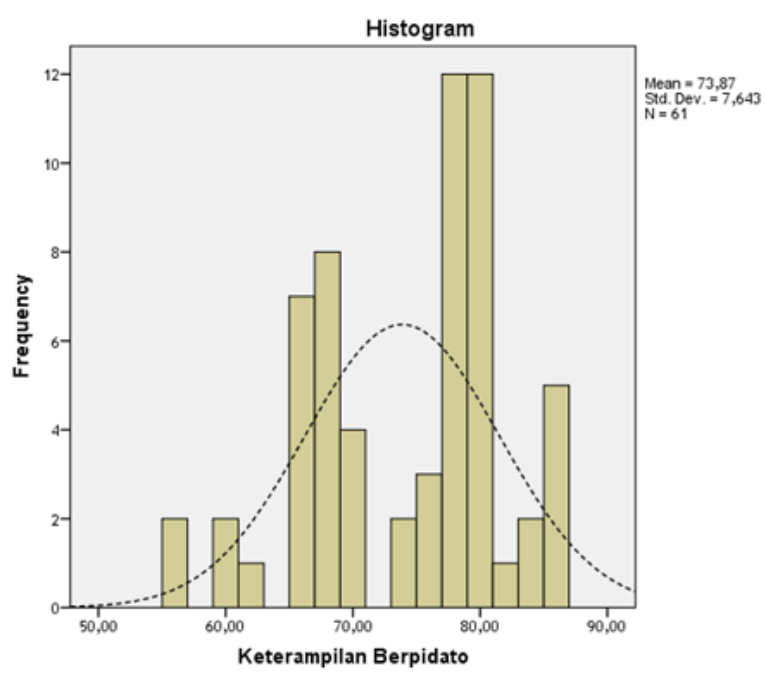

Dari histogram dan poligon frekwensi di atas dapat disimpulkan bahwa data keterampilan berpidato siswa MAN 6 Jakarta kampus B memiliki sebaran yang normal.

\section{Data Minat Membaca $\left(\mathrm{X}_{1}\right)$}

Data minat membaca diperoleh dari skor kuesioner yang dijawab oleh responden yang menjadi sampel penelitian sebanyak 61 siswa. Skor yang diperoleh terendah 56 , tertinggi 86,29 , rerata sebesar 69,89 , median 68,57, modus 65,71, dan simpangan baku 6,607.

Tabel 4.2 Deskripsi Data Penelitian Minat

Membaca

Statistics

\begin{tabular}{|c|l|r|}
\hline \multirow{2}{*}{$N$} & Valid & 61 \\
\cline { 2 - 3 } & Missing & 0 \\
\hline \multirow{7}{*}{} & Mean & 69,8946 \\
\cline { 2 - 3 } & Median & 68,5700 \\
\cline { 2 - 3 } & Mode & 65,71 \\
\cline { 2 - 3 } & Std. Deviation & 6,60724 \\
\cline { 2 - 3 } & Minimum & 56,00 \\
\cline { 2 - 3 } & Maximum & 86,29 \\
\hline
\end{tabular}

Dari hasil perhitungan di atas, maka bisa dikatakan bahwa minat membaca siswa MAN 6 Jakarta kampus B cukup. Hal ini di indikasikan dengan perolehan nilai rerata sebesar 69,89 melewati nilai mediannya.

Untuk memperjelas data di atas, digambar histogram sebagai berikut:

Gambar 4.2 Histogram Poligon Variabel Minat Membaca

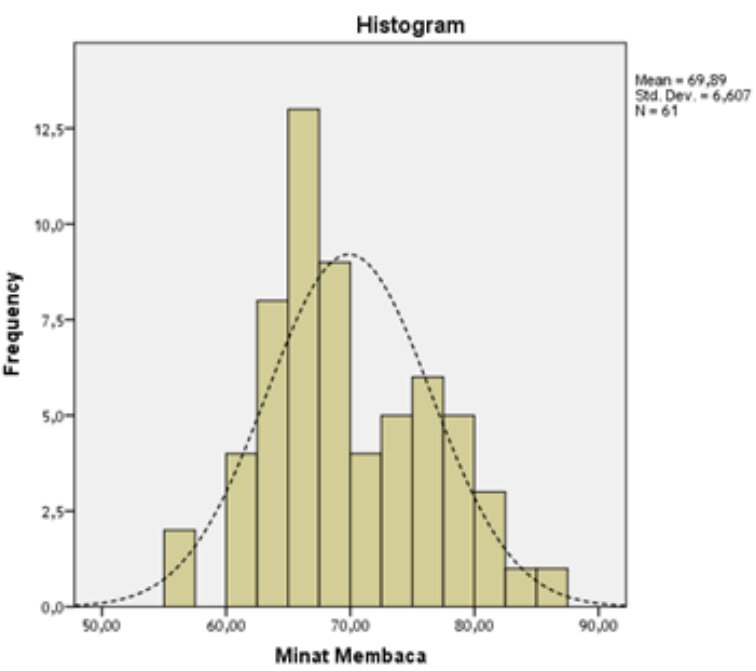

Dari histogram dan poligon frekwensi di atas dapat disimpulkan bahwa minat membaca siswa MAN 6 Jakarta kampus B memiliki sebaran yang normal.

3. Data Penguasaan Kosakata $\left(\mathrm{X}_{2}\right)$

Data penguasaan kosakata diperoleh dari skor kuesioner yang dijawab oleh responden yang menjadi sampel penelitian sebanyak 61 siswa sebagai responden dan menghasilkan nilai terendah 37 , tertinggi 80 , rerata sebesar 61,73 median sebesar 63, modus sebesar 63 dan simpangan baku sebesar 11,442 .

Tabel 4.3 Deskripsi Data Penelitian Penguasaan Kosakata

Statistics

\begin{tabular}{|c|l|r|}
\hline \multirow{2}{*}{$N$} & Valid & 61 \\
\cline { 2 - 3 } & Missing & 0 \\
\hline \multirow{3}{*}{} & Mean & 61,7377 \\
\cline { 2 - 3 } & Median & 63,0000 \\
\cline { 2 - 3 } & Mode & 63,00 \\
\cline { 2 - 3 } & Std. Deviation & 11,44247 \\
\cline { 2 - 3 } & Minimum & 37,00 \\
\cline { 2 - 3 } & Maximum & 80,00 \\
\hline
\end{tabular}


Dari hasil penghitungan di atas, maka bisa dikatakan bahwa penguasaan kosakata siswa MAN 6 Jakarta kampus B cukup. Hal ini diindikasikan dengan perolehan nilai rerata penguasaan kosakata sebesar 61,73 mendekati skor mediannya.

Untuk memperjelas data di atas, digambarkan dalam histogram sebagai berikut:

Gambar 4.3 Histogram Poligon Variable Penguasaan Kosakata

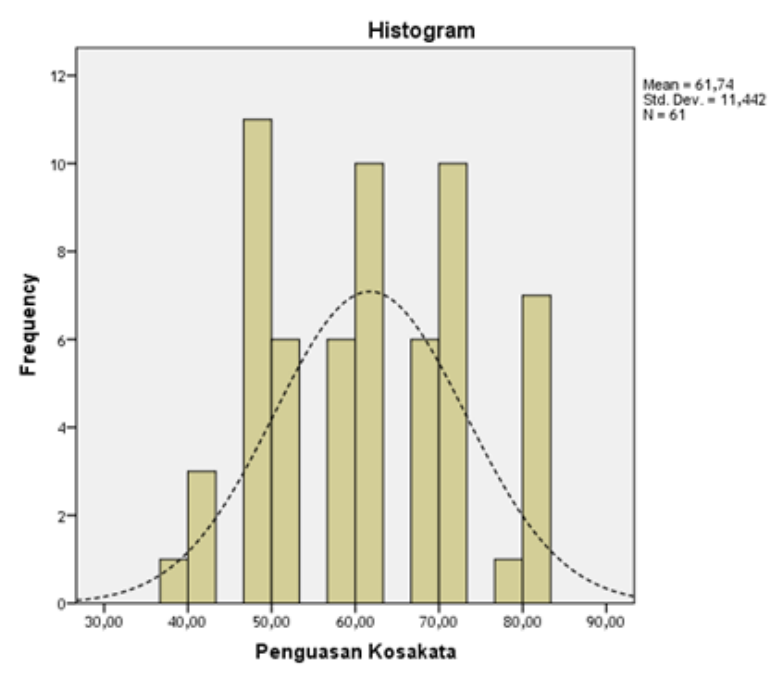

Dari histogram dan poligon frekwensi di atas dapat disimpulkan bahwa penguasaan kosakata siswa MAN 6 Jakarta kampus $B$ memiliki sebaran yang normal.

\section{Uji Persyaratan Analisis Regresi}

1. Uji Asumsi Klasik

a. Uji Normalitas Data

Persyaratan regresi yang baik jika data penelitian mengikuti distribusi normal.

Tabel 4.4 Uji Normalitas Data

One-Sample Kolmogorov-Smirnov Test

\begin{tabular}{|c|l|r|r|c|}
\hline \multicolumn{2}{|l|}{} & $\begin{array}{c}\text { Minat } \\
\text { Membaca }\end{array}$ & $\begin{array}{c}\text { Penguasaan } \\
\text { Kosakata }\end{array}$ & $\begin{array}{c}\text { Keterampilan } \\
\text { Berpidato }\end{array}$ \\
\hline \multirow{2}{|c|}{ N } & & 61 & 61 & 61 \\
\hline \multirow{2}{*}{$\begin{array}{l}\text { Normal } \\
\text { Parametersa, }\end{array}$} & Mean & 69,8946 & 61,7377 & 73,8689 \\
\cline { 2 - 5 } & $\begin{array}{l}\text { Std. } \\
\text { Deviation }\end{array}$ & 6,60724 & 11,44247 & 7,64303 \\
\hline
\end{tabular}

\begin{tabular}{|c|c|c|c|c|}
\hline \multirow{3}{*}{$\begin{array}{l}\text { Most Extreme } \\
\text { Differences }\end{array}$} & Absolute & 120 & ,122 & 214 \\
\hline & Positive & 120 & ,122 & 107 \\
\hline & Negative &,- 061 & -,101 &,- 214 \\
\hline $\begin{array}{l}\text { Kolmogorov- } \\
\text { Smirnov Z }\end{array}$ & & 941 & ,951 & 1,670 \\
\hline $\begin{array}{l}\text { Asymp. Sig. } \\
\text { (2-tailed) }\end{array}$ & & ,339 & ,327 & ,008 \\
\hline
\end{tabular}

Dari tabel di atas menunjukan bahwa uji hipotesis yang menyatakan distribusi data pada analisis regresi ini mengikuti distribusi normal. Hal ini ditunjukan dengan semua nilai Asymp. Sig $>0,05$. Hal ini berarti semua data berdistribusi normal.

b. Uji Multikolinearitas

Uji multikolinearitas bertujuan untuk menguji apakah model regresi ditemukan adanya korelasi yang sempurna antarvariabel bebas (independent). Model regresi yang baik seharusnya tidak terjadi korelasi yang sempurna di antara variabel bebas. Salah satu cara untuk mendeteksinya adanya multikolinearitas adalah dengan melihat tolerance atau varian inflation factor (VIF). Apabila tolerance $<0,1$ atau nilai VIF $>10$ maka terjadi multikolinearitas.

Tabel 4.5 Uji Multikolinearitas Coefficients $^{\mathrm{a}}$

\begin{tabular}{|l|c|c|c|c|c|}
\hline \multirow{2}{*}{ Model } & \multicolumn{3}{|c|}{ Correlations } & \multicolumn{2}{c|}{$\begin{array}{c}\text { Collinearity } \\
\text { Statistics }\end{array}$} \\
\cline { 2 - 4 } & $\begin{array}{l}\text { Zero- } \\
\text { order }\end{array}$ & Partial & Part & Tolerance & VIF \\
\hline $\begin{array}{l}\text { Minat } \\
\text { Membaca }\end{array}$ &, 576 &, 346 &, 243 &, 732 & 1,367 \\
\hline $\begin{array}{l}\text { Penguasaan } \\
\text { Kosakata }\end{array}$ &, 710 &, 589 &, 482 &, 732 & 1,367 \\
\hline
\end{tabular}

a. Dependent Variable: Keterampilan Berpidato

Hasil uji multikolinearitas pada tabel di atas diketahui bahwa hasil tolerance $0,732>0,1$ atau varian inflation factor (VIF) $1,367<10$. Sehingga dapat dinyatakan bahwa tidak ada multikolinearitas antara minat membaca 
dan penguasaan kosakata pada analisis regresi ganda ini.

c. Uji Heteroskesdatisitas

Pengertian heteroskesdatisitas adalah apabila kesalahan atau residual yang diamati tidakmemilikivarianyang konstan. Kondisi heteroskedastisitas sering terjadi pada data cross section, atau data yang diambil dari beberapa responden pada suatu waktu tertentu.

Salah satu metode untuk mendeteksi adanya heteroskedastisitas adalah dengan membuat scatter-plot antara Standardized Residual dan Unstandardized Predicted Value (Y topi). Pada gambar di bawah ini menunjukkan tidak ada perubahan e sepanjang Y topi, maka dinyatakan tidak ada heteroskedastisitas pada galat (error/residual) tersebut.

Gambar 4.3 Scatter-plot Uji Heteroskedastisitas

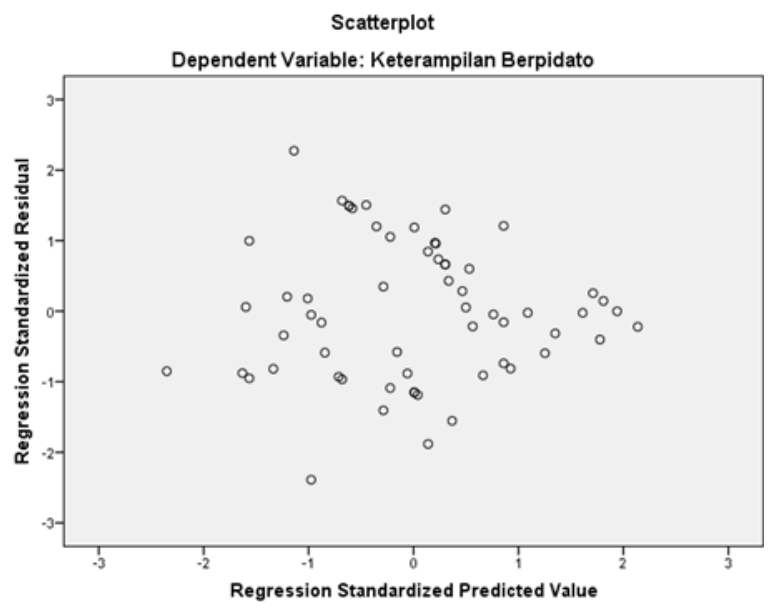

Dari gambar di atas menunjukan bahwa titik-titik menyebar secara acak dan tidak membentuk pola tertentu yang jelas, serta tersebar di atas maupun di bawah angka 0 dan pada sumbu Y. Hal ini menunjukan bahwa tidak terjadi heteroskedastisitas pada model regresi tersebut, sehingga dapat dipakai untuk memprediksi variabel keterampilan berpidato berdasarkan minat membaca dan penguasaan kosakata.

d. Uji Normalitas Galat

Persyaratan regresi yang baik jika data penelitian mengikuti distribusi normal.

Tabel 4.6 Uji Normalitas Galat

One-Sample Kolmogorov-Smirnov Test

\begin{tabular}{|l|l|c|}
\hline \multicolumn{2}{|c|}{ N } & $\begin{array}{r}\text { Unstandardized } \\
\text { Predicted Value }\end{array}$ \\
\hline \multirow{3}{*}{ Normal Parameters ${ }^{\mathrm{a}, \mathrm{b}}$} & Mean & 61 \\
\cline { 2 - 3 } & Std. Deviation & 73,8688525 \\
\hline \multirow{3}{*}{ Most Extreme Differences } & Absolute &, 048 \\
\cline { 2 - 3 } & Positive &, 048 \\
\cline { 2 - 3 } & Negative &,- 045 \\
\hline Kolmogorov-Smirnov Z & &, 375 \\
\hline Asymp. Sig. (2-tailed) & &, 999 \\
\hline \\
$\begin{array}{l}\text { a. Test distribution is Normal. } \\
\text { b. Calculated from data. }\end{array}$
\end{tabular}

Dari tabel di atas menunjukan bahwa uji hipotesis yang menyatakan distribusi residual pada analisis regresi ini mengikuti distribusi normal. Hal ini ditunjukan dengan nilai $Z=0,375$ dan Sig $=0,999>0,05$. Hal ini berarti asumsi atau persyaratan analisis regresi terpenuhi.

2. Uji Linearitas

Uji linearitas dilakukan untuk menentukan teknik dalam analisis regresi variabel bebas $\left(\mathrm{X}_{1}\right.$ dan $\left.\mathrm{X}_{2}\right)$ dan variabel terikat (Y) terbentuk linear. Uji linearitas ini menggunakan perhitungan SPSS. 20.0

a. Linearitas regresi pengaruh variabel $\mathrm{X}_{1}$ atas $\mathrm{Y}$

Hasil uji linearitas regresi antara Minat Membaca dengan Keterampilan Berpidato, menggunaka SPSS 20.0 sebagai berikut: 
Tabel 4.7 Hasil Pengujian Linearitas Regresi Y

atas $\mathrm{X}$

ANOVA Table

\begin{tabular}{|c|c|c|c|c|c|c|c|}
\hline & & & Sum of Squares & $\mathrm{df}$ & \begin{tabular}{|l|} 
Mean Square \\
\end{tabular} & $\bar{F}$ & Sig. \\
\hline \multirow{7}{*}{$\begin{array}{l}\text { Keterampil } \\
\text { an } \\
\text { Berpidato* } \\
\text { Minat } \\
\text { Membaca }\end{array}$} & \multirow{5}{*}{$\begin{array}{l}\text { Between } \\
\text { Groups }\end{array}$} & (Combined) & 2473,617 & 36 & 68,712 & \multirow{3}{*}{$\begin{array}{r}1,599 \\
27,079\end{array}$} & \multirow{3}{*}{$\begin{array}{l}, 115 \\
, 000\end{array}$} \\
\hline & & Linearity & 1163,660 & \multirow[t]{2}{*}{1} & \multirow[t]{2}{*}{1163,660} & & \\
\hline & & Deviation & \multirow{3}{*}{1309,958} & & & & \\
\hline & & from & & \multirow[t]{2}{*}{35} & \multirow[t]{2}{*}{37,427} & \multirow[t]{2}{*}{871} & \multirow[t]{2}{*}{,652 } \\
\hline & & Linearity & & & & & \\
\hline & \multicolumn{2}{|c|}{ Within Groups } & 1031,333 & 24 & \multirow[t]{2}{*}{42,972} & & \\
\hline & \multicolumn{2}{|l|}{ Total } & 3504,951 & 60 & & & \\
\hline
\end{tabular}

Berdasarkan hasil penghitungan di atas diperoleh hasil perhitungan Deviation from Linearity dengan $\mathrm{F}_{0}=$ 0,871 dan Sig. $=0,652>0,05$. Hal ini memiliki pengertian bahwa variabel minat membaca dengan keterampilan berpidato siswa mempunyai hubungan yang linear.

b. Linearitas regresi pengaruh variabel $\mathrm{X}_{2}$ atas $\mathrm{Y}$

Hasil uji linearitas regresi antara Penguasaan Kosakata dengan Keterampilan Berpidato perhitungan SPSS 20.0 sebagai berikut:

Tabel 4.8 Hasil Pengujian Linearitas Regresi Variabel $\mathrm{Y}$ atas $\mathrm{X}_{2}$

\section{ANOVA Table}

\begin{tabular}{|c|c|c|c|c|c|c|c|}
\hline & & & Sum of Squares & $\mathrm{df}$ & Mean Square & $\overline{\mathrm{F}}$ & Sig. \\
\hline \multirow{6}{*}{$\begin{array}{l}\text { Keterampilan } \\
\text { Berpidato* } \\
\text { Penguasaan } \\
\text { Kosakata }\end{array}$} & \multirow{4}{*}{$\begin{array}{l}\text { Between } \\
\text { Groups }\end{array}$} & (Combined) & \multirow{2}{*}{$\begin{array}{l}2013,991 \\
1769,043\end{array}$} & \multirow[t]{3}{*}{12} & \multirow{2}{*}{$\begin{array}{r}167,833 \\
1769,043\end{array}$} & \multirow{2}{*}{$\begin{array}{r}5,403 \\
56,953\end{array}$} & \multirow{3}{*}{$\begin{array}{l}, 000 \\
, 000\end{array}$} \\
\hline & & Linearity & & & & & \\
\hline & & Deviation & \multirow{2}{*}{244,949} & & \multirow{2}{*}{22,268} & \multirow{2}{*}{, 717} & \\
\hline & & & & 11 & & & .717 \\
\hline & \multicolumn{2}{|c|}{ Within Groups } & 1400960 & 48 & \multirow{2}{*}{31,062} & & \\
\hline & \multicolumn{2}{|l|}{ Total } & 3504,951 & 60 & & & \\
\hline
\end{tabular}

Berdasarkan hasil perhitungan di atas diperoleh hasil Deviation from Linearity dengan $\mathrm{F}_{0}=0,717$ dan Sig. $=0,717>0,05$. Hal ini memiliki pengertian bahwa variabel penguasaan kosakata dengan keterampilan berpidato siswa mempunyai hubungan yang linear.

\section{Pengujian Hipotesis}

Pengujian hipotesis dilakukan sesuai dengan ketentuan yang telah dijelaskan dalam Bab III. Hasil perhitungan dan pengujian bisa dilihat pada tabel-tabel dibawah ini:

Tabel 4.9. hasil perhitungan Pengujian Koefisisen Korelasi Ganda Variabel $\mathrm{X}_{1}$ dan $\mathrm{X}_{2}$ terhadap Y

\section{Model Summary ${ }^{b}$}

\begin{tabular}{|c|c|c|c|c|} 
Model & $\mathbf{R}$ & R Square & $\begin{array}{c}\text { Adjusted R } \\
\text { Square }\end{array}$ & $\begin{array}{c}\text { Std. Error } \\
\text { of the Estimate }\end{array}$ \\
\hline 1 &, $751^{\mathrm{a}}$ &, 564 &, 549 & 5,13298 \\
\hline
\end{tabular}

a. Predictors: (Constant), Penguasaan Kosakata, Minat Membaca

b. Dependent Variable: Keterampilan Berpidato

Tabel 4.10. Hasil Perhitungan Pengujian

Signifikansi Koefisien Regresi

Variabel $\mathrm{X}_{1}$ dan $\mathrm{X}_{2}$ terhadap $\mathrm{Y}$

\begin{tabular}{|l|l|r|r|r|r|c|}
\multicolumn{7}{|c|}{ ANOVA $^{\text {b }}$} \\
\hline \multirow{2}{*}{ Model } & $\begin{array}{c}\text { Sum of } \\
\text { Squares }\end{array}$ & df & $\begin{array}{c}\text { Mean } \\
\text { Square }\end{array}$ & F & Sig \\
\hline \multirow{2}{*}{1} & Regression & 1976,795 & 2 & 988,398 & 37,514 &, $000 \mathrm{~b}$ \\
\cline { 2 - 7 } & Residual & 1528,155 & 58 & 26,348 & & \\
\cline { 2 - 8 } & Total & 3504,951 & 60 & & & \\
\hline
\end{tabular}

a. Dependent Variable: Keterampilan Berpidato

b. Predictors: (Constant), Penguasaan Kosakata, Minat Membaca

Tabel 4.11. Hasil Perhitungan Persamaan Regresi Ganda Variabel X1 dan X2 terhadap Y

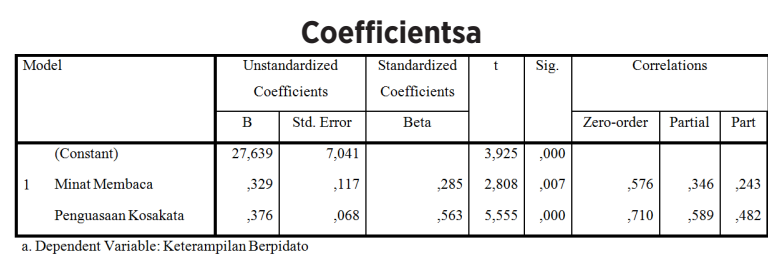

1. Pengaruh Minat Membaca $\left(\mathrm{X}_{1}\right)$ dan Penguasaan Kosakata $\left(\mathrm{X}_{2}\right)$ secara bersamasama terhadap Keterampilan Berpidato (Y).

Hipotesis yang diuji:

$\mathrm{H}_{0}=\beta_{\mathrm{y} 1}=\beta_{\mathrm{y} 2}=0$

$\mathrm{H}_{1}=\beta_{\mathrm{y} 1} \neq 0$ atau $\beta_{\mathrm{y} 2} \neq 0$

Artinya,

$\mathrm{H}_{0}=$ tidak terdapat pengaruh yang signifikan minat membaca dan penguasaan kosakata secara bersamasama terhadap keterampilan ber- 
pidato siswa.

$\mathrm{H}_{1}=$ terdapat pengaruh yang signifikan minat membaca dan penguasaan kosakata secara bersama-sama terhadap keterampilan berpidato siswa.

Dari tabel 4.10 dapat dinyatakan bahwa terdapat pengaruh yang signifikan minat membaca dan penguasaan kosakata secara bersama-sama terhadap keterampilan berpidato. Hal ini dibuktikan dengan perolehan nilai $\mathrm{F}_{0}=37,514$ dan Sig. $=0,000<0,5$.

Sementara itu, persamaan garis regresi ganda dapat dinyatakan dengan $\hat{\mathrm{Y}}=$ $27,639+0,329+0,376$. Hal ini memiliki pengertian bahwa kenaikan satu skor variabel minat membaca dan penguasaan kosakata memberikan kontribusi terhadap keterampilan sebesar 0,329 untuk variabel $\mathrm{X}_{1}$ dan 0,376 untuk variabel $\mathrm{X}_{2}$. Dari tabel 4.9 juga dapat menjelaskan bahwa secara bersama-sama variabel minat membaca dan penguasaan kosakata memberikan kontribusi sebesar 56,4\% terhadap variabel keterampilan berpidato.

2. Pengaruh Minat Membaca $\left(\mathrm{X}_{1}\right)$ terhadap Keterampilan Berpidato (Y)

Hipotesis yang diuji:

$\mathrm{H} 0: \mathrm{B}_{\mathrm{y} 1}$

$\mathrm{H} 1: \beta_{\mathrm{y} 1} \neq 0$

Artinya,

$\mathrm{H}_{0}=$ tidak terdapat pengaruh yang signifikan minat membaca terhadap keterampilan berpidato siswa

$\mathrm{H}_{1}=$ terdapat pengaruh yang signifikan minat membaca terhadap keterampilan berpidato siswa.

Dari tabel 4.11 dapat dinyatakan bahwa terdapat pengaruh yang signifikan minat membaca terhadap keterampilan berpidato. Hal ini dibuktikan dengan perolehan nilai $\mathrm{t}_{\text {hitung }}=2,808$ dan Sig. $=0,007$ $<0,05$.

Adapun kontribusi variabel Minat Membaca terhadap Keterampilan Berpidato dapat dinyatakan dengan rumus,
$\mathrm{KD}=$ Nilai $\mathrm{B}_{\mathrm{x} 1 \mathrm{y}} \mathrm{x}$ Nilai Korelasi Parsialnya $\left(\mathrm{r}_{\mathrm{x} 1 \mathrm{y}}\right) \times 100 \%$

$\mathrm{KD}=0,285 \times 0,576 \times 100 \%=16,41 \%$

Dari hasil perhitungan di atas dapat dinyatakan bahwa kontribusi Minat Membaca dalam meningkatkan keterampilan berpidato sebesar $16,41 \%$.

3. Pengaruh Penguasaan Kosakata $\left(\mathrm{X}_{2}\right)$ terhadap Keterampilan Berpidato (Y)

Hipotesis yang diuji:

$\mathrm{H}_{0}: \mathrm{B}_{\mathrm{y} 2}$

$\mathrm{H}_{1}: \mathrm{B}_{\mathrm{y} 2} \neq 0$

Artinya,

$\mathrm{H}_{0}=$ tidak terdapat pengaruh yang signifikan penguasaan kosakata terhadap keterampilan berpidato siswa.

$\mathrm{H}_{1}=$ terdapat pengaruh yang signifikan penguasaan kosakata terdapat keterampilan berpidato siswa.

Dari tabel 4.11. dapat dinyatakan bahwa terdapat pengaruh yang signifikan penguasaan kosakata terhadap keterampilan berpidato. Hal ini dibuktikan dengan perolehan nilai $\mathrm{t}_{\text {hitung }}=5,555 \mathrm{dan}$ Sig. $=0,000<0,05$.

Adapun kontribusi variabel penguasan kosakata terhadapa keterampilan berpidato dapat dinyatakan dengan rumus,

$\mathrm{KD}=$ Nilai $\mathrm{B}_{\mathrm{x} 2 \mathrm{y}} \mathrm{x}$ Nilai Korelasi Parsialnya $\left(\mathrm{r}_{\mathrm{x} 2 \mathrm{y}}\right) \times 100 \%$

$\mathrm{KD}=0,563 \times 0,710 \times 100 \%=39,97 \%$

Dari penghitungan di atas dapat dinyatakan bahwa kontribusi penguasaan kosakata dalam meningkatkan keterampilan berpidato sebesar $39,97 \%$.

\section{Pembahasan}

1. Pengaruh Minat Membaca $\left(\mathrm{X}_{1}\right)$ dan Penguasaan Kosakata $\left(\mathrm{X}_{2}\right)$ terhadapa Keterampilan Berpidato (Y)

Hasil penelitian dia atas menyimpulkan bahwa minat membaca dan penguasaan kosakata secara bersama-sama memberikan pengaruh positif terhadap peningkatan keterampilan berpidato siswa MAN 6 
Jakarta kampus B. Hal ini mengandung arti bahwa minat membaca dan penguasaan kosakata telah memberikan kontribusi dan pengaruh yang signifikan terhadap peningkatan keterampilan berpidato siswa MAN 6 Jakarta kampus B.

Berbicara adalah keterampilan berbahasa yang digunakan secara lisan. Salah satu sarana untuk melatih keterampilan berbicara siswa di sekolah yang dapat dipilih adalah berpidato. Manfaat yang dapat dipetik dari pidato tersebut disamping siswa memiliki disiplin dalam berbicara, lafal yang wajar serta informasi yang wajar pula. Berpidato dapat melatih keberanian dan ketangguhan mental siswa di depan orang banyak.

Berpidato merupakan keterampilan berbicara di muka umum untuk menyampaikan pikiran, gagasan, pendapat perasaan, dan pesan-pesan khusus dari seseorang yang melakukannya. Dalam berpidato memerlukan persiapan, teknik serta keterampilan dan seni untuk mempengaruhi para pendengarnya. Seseorang dapat berpidato dengan mahir tidak hanya disebabkan oleh faktor bakat dan latihan yang rutin saja. Namun ditentukan pula oleh wawasan yang luas pada suatu bidang tertentu yang bisa diperoleh dengan membaca dan kemampuan penguasaan kosakata juga memberikan kontribusi yang banyak.

Apa bila dicermati lebih mendalam, ada faktor dalam diri siswa sebagai faktor dominan yang juga berpengaruh dalam pembelajaran pidato. Faktor yang diduga sebagai penyebab rendahnya keterampilan berpidato adalah rendahnya pengetahuan tentang kaidah bahasa yang berlaku, minimnya penguasaan kosakata, dan terbatasnya pengetahuan dan wawasan yang kesemuanya itu bisa dicapai dengan membaca dan didorong oleh minat membaca. Tarigan (2013:2) mengatakan bahwa kualitas keterampilan berbahasa seseorang jelas bergantung pada kualitas dan kuatitas kosakata yang dimilikinya.

2. Pengaruh Minat Membaca $\left(\mathrm{X}_{1}\right)$ terhadap Keterampilan Berpidato (Y)

Hasil penelitian di atas menyimpulkan bahwa Minat Membaca telah memberikan pengaruh yang positifterhadap peningkatan keterampilan berpidato siswa MAN 6 Jakarta kampus B. Hal ini mengandung arti bahwa minat membaca siswa memberikan pengaruh yang cukup signifikan terhadap peningkatan keterampilan berpidato MAN 6 Jakarta kampus B.

Salah satu faktor yang mempengaruhi keterampilan berpidato adalah minat membaca. Minat membaca yang tinggi akan mendoronng siswa untuk aktif membaca dan gemar membaca, sehingga pada gilirannya ia mendapatkan informasi, bertambah wawasan dan pengetahuanya juga sekaligus menambah perbendaharaan kata yang dimilikinya. Dengan perolehan seperti itu akan mendukung siswa untk terampil berpidato.

Satu di antara faktor pendukung minat membaca siswa adalah perpustakaan sekolah. Perpustakaan sebagai sumber informasi ilmu pengetahuan harus benar-benar dapat memaikan perananya. Bahkan ada yang mengatakan bahwa perpustakaan adalah jantung sekolah. Sekolah yang perpustakaannya hidup akan berkembang pesat dan lebih maju, sebaliknya sekolah yang perpustakaannya mati, pengembangan ilmu pengetahuan dari sekolah tersebut juga akan terhambat dan mati.

Kegiatan membaca akan menjadi bermakna dan bermanfaat apabila didorong oleh minat membaca yang tinggi. Sayangya, tidak semua siswa memiliki minat membaca yang tinggi. Minat membaca yang rendah diduga sebagai pemicu rendahnya penguasaan kosakata. Dengan demikian, siswa yang minat membacanya rendah 
akan rendah pula peguasaan kosakatanya. Menurut Tarigan (2006:53) tanpa kemampuan berbicara yang baik siswa tidak akan mampu mengeskpresi, menyatakan, dan menyampikiran, gagasan dan perasaannya dengan baik. Keterampilan berpidato siswa tidak dapat dimiliki secara tiba-tiba, tetapi harus melalui pelatihan yang rutin dan konsisten serta didukung oleh wawasan yang luas.

3. Pengaruh Penguasaan Kosakata $\left(\mathrm{X}_{2}\right)$ terhadap Keterampilan Berpidato (Y)

Dari hasil penelitian dan kajian teori di atas dapat disimpulkan bahwa penguasaan kosakata telah memberikan kontribusi dan pengaruh yang positif terhadap keterampilan berpidato. Artinya, kemampuan penguasaan kosakata siswa telah memberikan pengaruh yang signifikan terhadap keterampilan berpidato siswa MAN 6 Jakarta kampus B.

Faktor lain yang menjadi penyebab rendahnya keterampilan berpidato siswa adalah rendahnya pengetahuan kaidah bahasa yang berlaku, dalah satunya adalah rendahnya penguasaan kosakata. Kualitas dan kuantitas penguasaan kosakata akan menentukan kualitas kalimat dan mutu berbicara seseorang.

Berbicara adalah bahasa lisan yang digunakan dalam komunikasi dua arah dan terkait erat dengan pengucapan lafal suatu kata. Pengucapan lafal suatu kata artinya adalah kemampuan menguasai kosakata baik pengucapan atau pemaknaan. Ketermilikan penguasaan ini akan mendukung keterampilan berpidato seseorang.

Meskipun berpidato adalah seni bertutur di hadapan orang banyak atau dimuka umum yang bisa dilatih secara rutin dan bertahap, tanpa adanya wawasan yang luas informasi yang ingin disampaikan dan minimnya penguasaan kosakata, maka kegiatan berpidato akan terhambat dan keterampilan berpidato menjadi rendah.

\section{KESIMPULAN DAN SARAN \\ Kesimpulan}

Hasil penelitian yang diperoleh di lapangan sebagai berikut,

1. Terdapat pengaruh yang signifikan minat membaca dan penguasaan kosakata secara bersama-sama terhadap keterampilan berpidato siswa MAN 6 Jakarta. Hal ini dibuktikan dengan perolehan Nilai $\mathrm{F}_{0}=\mathrm{F}_{0}$ $=37,514$ dan Sig. $=0,000<0,5$. Secara bersama-sama variabel kedisiplinan dan motivasi belajar memberikan kontribusi sebersar $56,4 \%$ terhadap varibel keterampilan berpidato.

2. Terdapat pengaruh yang signifikan minat membaca terhadap keterampilan berpidato siswa MAN 6 Jakarta. Hal ini dibuktikan dengan perolehan nilai $\mathrm{t}_{\text {hitung }}=2,808$ dan Sig. $=0,007<0,05$. Variabel kedisiplinan memberikan kontribusi sebesar 16,41\% dalam keterampilan berpidato MAN Jakarta.

3. Terdapat pengaruh yang signifikan penguasaan kosakata terhadap keterampilan berpidato siswa MAN 6 Jakarta. Hal ini dibuktikan dengan perolehan nilai $\mathrm{t}_{\text {hitung }}=$ 5,555 dan Sig. $=0,000<0,05$ Variabel motivasi belajar memberikan kontribusi sebesar 39,97\% dalam keterampilan berpidato.

\section{Implikasi}

Berdasarkan kesimpulan di atas, maka khususnya guru bahasa Indonesia dan umumnya semua tenaga pendidik diharapkan dapat meningkatkan prestasi belajar siswa. Pada tataran pemahaman maupun dalam praktiknya yang juga otomatis berbeda. Mengingat penelitian ini menyangkut masalah sumber daya manusia, maka dalam menjawab pertanyaan dan pernyataan kelihatannya responden sangat hati-hati dan ada di antaran tidak terungkap secara nyata, utamanya hal-hal menyangkut 
tentang dirinya, sehingga masih diperlukan pengungkapan faktor-faktor tersebut dalam suasana yang lebih spesifik dan transparan serta diperlukan juga pelatihan secara rutin dalam praktik berpidato. Bertolak dari kenyataan di atas, sangat diperlukan adanya upaya untuk mengungkap beberapa aspek tersebut melalui suatu observasi atau wawancara dengan pihak sekolah. Juga perlu penelitian lebih lanjut untuk mengungkap faktor yang lain yang dianggap berpengaruh namun belum terungkap dalam penelitian ini.

\section{Saran}

Berdasarkan hasil penelitian, kesimpulan dan implikasi penulis mengajukan beberapa saran sebagai berikut:

1. Hendaknya para guru selalu berusaha untuk mengkondisikan agar siswa mempunyai kedisiplinan yang tinggi.

2. Hendaknya para guru bahasa Indonesia mengupayakan agar siswa meningkatkan motivasi belajar bahasa Indonesia sebaikbaiknya.

3. Perbedaan motif, tujuan, dan kebutuhan siswa menyebabkan perlunya peningkatan prestasi belajar siswa. Dalam hal ini sekolah agar mendukung dan memfasilitasi sarana dan prasarana kegiatan.

4. Guru sebagai pengajar, diharapkan dapat memberikan prioritas terhadap kedisiplinan dan motivasi belajar pada saat mengajar para siswanya, sehingga prestasi belajar dapat tercapai dengan baik.

\section{DAFTAR PUSTAKA}

Adiwimarta, dkk. 1998. Tata Bahasa Indonesia. Jakarta: Pusat Pembinaan Pengembangan Bahasa

Akhadiyat, Subarti. 1986. Menulis II. Jakarta: Universitas Terbuka

Aminuddin. 1998. Semantik; Pengantar Studi Tentang Makna. Bandung: Sinar Batu

Alwi, Hasan. 2001. Kamus Besar Bahasa Indonesia. Jakarta: Balai Pustaka.
-2003. Tata Bahasa Baku Bahasa Indonesia. Jakarta: Balai Pustaka.

Arifin, Zaenal. 1995. Cermat Berbahasa Indonesia. Jakarta: Akademi Presindo

Arikunto, Suharsimi. 1994. Prosedur Penelitian Suatu Pendekatan Praktik. Jakarta: Rineka Cipta.

Azwar, S. 2010. Tes Prestasi: Fungsi dan Pengembangan Pengukuran Prestasi Belajar. Edisi II. Yogyakarta: Pustaka Pelajar.

Bloom, Benjamin S. 1954. Taxonomy of Education Objectives: The Classification of Educations Goals. London: David McKay Company, Inc.

Bloomfield, Leonard. 1995. Language. Terjemahan I. Sutikno. Jakarta: PT. Gramedia Pustaka Utama

Brown, H. Douglas. 2001. Teaching by Principles: An Interactive Approach to Laguage Pedagogy, Second Edition. San Francisco State University : Addision Wesley Lougman.

Chaer, Abdul. 1993. Pengantar Semantik. Jakarta: Rineka Cipta

Chaedar. Alwasilah. 1993. Linguistik; Suatu Pengantar. Bandung: Angkasa.

Dardjowidjoyo, Soejono. 2012. Psikolinguistik; Pengantar Pemahaman Bahasa Manusia. Jakarta: Yayasan Pustaka Obor

Djali, dan Muljono, Pudji. 2008. Pengukuran dalam Bidang Pendidikan. Jakarta: Grasindo

Hadinegoro, Lukman.2003. Teknik Seni Berpidato Mutakhir. Yogyakarta: Penerbit Absolut

Keraf, Gorys. 1984. Diksi dan Gaya Bahasa. Ende, Flores: Nusa Indah

Nurgiyantoro, Burhan. 2010. Penilaian Pembelajaran Bahasa. Yogyakarta: BPFE

Nugrahani, Farida. 2009. Metodologi Penelitian Kualitatif. Surakarta: Sebelas Maret University Press.

(2011). Pedoman Penulisan Proposal Tesis dan Tesis. Sukoharjo: PPS Universitas Veteran Bangun Nusantara. 
Rahmat, Jalaludin. 2002. Retorika Modern Pendekatan Praktis. Bandung: PT. Remaja Rosdakarya

Roekhan dan Martutik. (1991). Evaluasi Pengajaran Bahasa Indonesia. Malang: Yayasan Asih Asah Asuh.

Slameto. 2003. Belajar Faktor-Faktor yang Mempengaruhi. Jakarta: Rineka Cipta

Slamet, St.Y. 2009. Dasar-dasar Keterampilan Berbahasa Indonesia. LPP UNS dan UNS Press. Surakarta.

Sugiyono. 1999. Statistik untuk Penelitian. Bandung: Alfabeta

--------. 2013. Cara Mudah Menyusun Skripsi, Tesis dan Disertasi (STD). Bandung: Alfabeta

Sugono, Dendy. 2009. Mahir Berbahasa Indoneseia dengan Benar. Jakarta: PT. Gramedia Pustaka Utama

Sujianto,J.Ch. 1988. Keterampilan Berbahasa Membaca-Menulis-Berbicara untuk Mata Kuliah Dasar Umum Bahasa Indonesia. Jakarta: Departemen P dan K

Supardi, US. 2012. Aplikasi Statistika dalam Penelitian. Jakarta: Ufuk Press.

Suparman, IA. 2013. Aplikasi Komputer dalam Penyusunan Karya Ilmiah. Jakarta: Pustaka Mandiri

Suwarto, 2003. "Evaluasi Pemanfaatan Laboratorium Biologi SMU se Kabupaten Sukoharjo" dalam Tesis. Program Pascasarjana (S2) Universitas Negeri Yogyakarta

-------, 2008. Jenis-jenis dan Karakteristik Tes. Sukoharjo: UNIVET

-------, 2011. "Pengembangan Tes Diagnostik untuk Mengungkap Kesulitan Siswa dalam Memahami Reproduksi Sel" dalam Disertasi. Program Pascasarjana (S3), Universitas Negeri Yogyakarta.

------. 2013. Pengembangan Tes Diagnostik dalam Pembelajaran. Yogyakarta: Pustaka Pelajar

Tarigan, Henry Guntur. 2013. Berbicara; Sebagai Suatu Keterampilan Berbahasa.
Bandung: Angkasa

Sebagai Suatu Keterampilan Berbahasa. Bandung: Angkasa.

Tidjan. 1993. Pengajaran Kosakata. Bandung : Angkasa

Waluyo, Herman.J. 1992. Penelitian Pendidikan Bahasa dan Sastra. Surakarta: Sebelas Maret University Press.

Yamin, Martinis. 2007. Kiat Membelajarkan Siswa. Jakarta: Gaung Persada Pres. 